\title{
No Generalizable Effect of Income Inequality on Public Support for Redistribution among Rich Democracies 1987-2010.
}

\author{
Nate Breznau, University of Bremen, Germany \\ Carola Hommerich, Hokkaido University, Sapporo, Japan
}

\begin{abstract}
We revisit a longstanding hypothesis that the public become more supportive of redistributive policy as income inequality rises. Previous tests of this hypothesis using various forms of general least squares regressions are inconclusive. We suggest improvements and alternatives to these tests. Using the World Inequality Data and International Social Survey Program we analyze 91 surveys in 18 countries. We incorporate three alternative measures of income inequality, including a measure of liberalization as a known cause of income inequality increases. We also employ two alternative test formats that arguably reflect the data generating model better than a least squares regression. The first is vector-autoregression aiming to account for path dependency of public opinion and income inequality, and the endogeneity between them. Next is qualitative comparative analysis to capture sets of conditions that collectively should have led to inequality having an impact on public opinion. Finally, we run our regression models separately for low and high socio-economic strata. In all tests we find no measurable impact of income inequality on support for redistribution. From a macro-perspective we argue that this suggests ruling out a general effect that exists across space and time, and focusing instead on theory to explain why there should not be a general effect. Some arguments suggest the public are normatively opposed to what sounds like 'handouts'. We therefore discuss model specification via theory, but also Type II errors, statistical power and the limitations of our conclusions.
\end{abstract}




\section{THE NEW ERA OF INEQUALITY}

Income inequality increased in almost all rich democracies from 1980 to 2010. Mainly as an increase of income concentration at the top of the distribution, where the taxable income share owned by the top $10 \%$ doubled and tripled across these societies in this period; including social democratic Sweden and the liberal United States (WID 2018). Income inequality is an indicator of complex causal processes leading to increasing wealth inequality, poverty and crime, and worsening public health (Hill and Jorgenson 2018; Pickett and Wilkinson 2015; Rambotti 2015). One cause is reductions in state socio-economic intervention, for example decreases in upper income and capital tax burdens, coordination of economic activity and provisions of social security produce more inequality of both gross and net incomes (Alvaredo et al. 2017; Bergh 2005; Korpi 1985; Korpi and Palme 1998; Mahler and Jesuit 2006).

The 1980s marked a mainstreaming of neoliberal ideological movements with figures such as Regan, Thatcher and Kohl coming into power (see also Hall and Thelen 2009; Pierson 2000b). Moreover, globalization and financialization exploded returns on capital. From 1980 to 2010, there was unprecedented cross-national integration of trade, investment, surety, security, lending and other forms of finance, and a steady increase in the concentration of income at the top of the distribution. If states kept their redistributive policies the same or liberalized them, this meant a decrease in social security, welfare, life quality and chances for upward mobility for a majority in many societies (Corak 2013; Krueger 2012; Neckerman and Torche 2007).

Liberalization generates economic growth for corporations and capital-investments by removing some of their cost burdens, but comes with an increase in inequality - an efficiency-equality tradeoff at the expense of those at the lower end of the income distribution (Okun 1975). If both top and bottom increased proportionally, societies could maintain their income distributions (Piketty 2014). However, the real wages of those in the working classes increased little, or even decreased in the period 1980-2010, thus labor did not grow proportionally to productivity (Thelen 2014). Moreover, overall there was economic shrinkage, not growth. Economic stagnation appeared as growth because of the sharp gains at the top (Western 1999). For example, GDP year-over-year growth declined globally from just above 4\% before 1980 to under 2\% after 2010 (World Bank 2017). Top-end growth provides 'evidence' for policymakers to support liberalization in addition to typical arguments about inefficiency, liberty and moral hazard (Friedman 2002).

Through privatization and power concentration at the top, education and family policies wane and increase the burden on lower and irregular income families (Beller and Hout 2006; Klenner 2013). Families with lower incomes in societies with higher levels of income inequality lack the financial resources to secure educational attainment and promote occupational mobility among their children. They experience earning-potential stagnation over time relative to those with higher incomes (Corak 2013; Jerrim and Macmillan 2015). 
Figure 1 offers evidence of various increases in income inequality in 18 rich democracies. We selected three measures of inequality based on data availability and attempts to cast a wider net in our research question. First, the top $10 \%$ cumulative share of the pre-fiscal taxable income distribution from World Inequality Data (WID 2017). This measure is advantageous because it accounts for the richest individuals generally not sampled in surveys such as the Luxembourg Income Study (LIS) and for the asymmetrical nature of pension systems which otherwise obscure measurement of "income" in retirement age persons cross-nationally. Critically, it measures the area of the income distribution where the big changes took place since 1980 (Piketty and Saez 2014). We also use the classic Gini measure of reported post-fiscal income mostly taken from the LIS (Solt 2017) ${ }^{1}$. Also, borrowing from Kwon (2016), we use a third measure of the Fraser Institute's scale of economic freedom. This measures the 'liberalness' of the state in economic regulations over time, thus tracking the process of liberalization by society. This final measure helps us target the mechanism of policy liberalization that causes inequality rather than the outcome of inequality itself.

\footnotetext{
${ }^{1}$ We use the stochastic Gini. Although Solt set up a dataset designed to use multiple imputation methods to give confidence intervals to non-Western and less wealthy countries, the countries we investigate have consistent Gini data.
} 


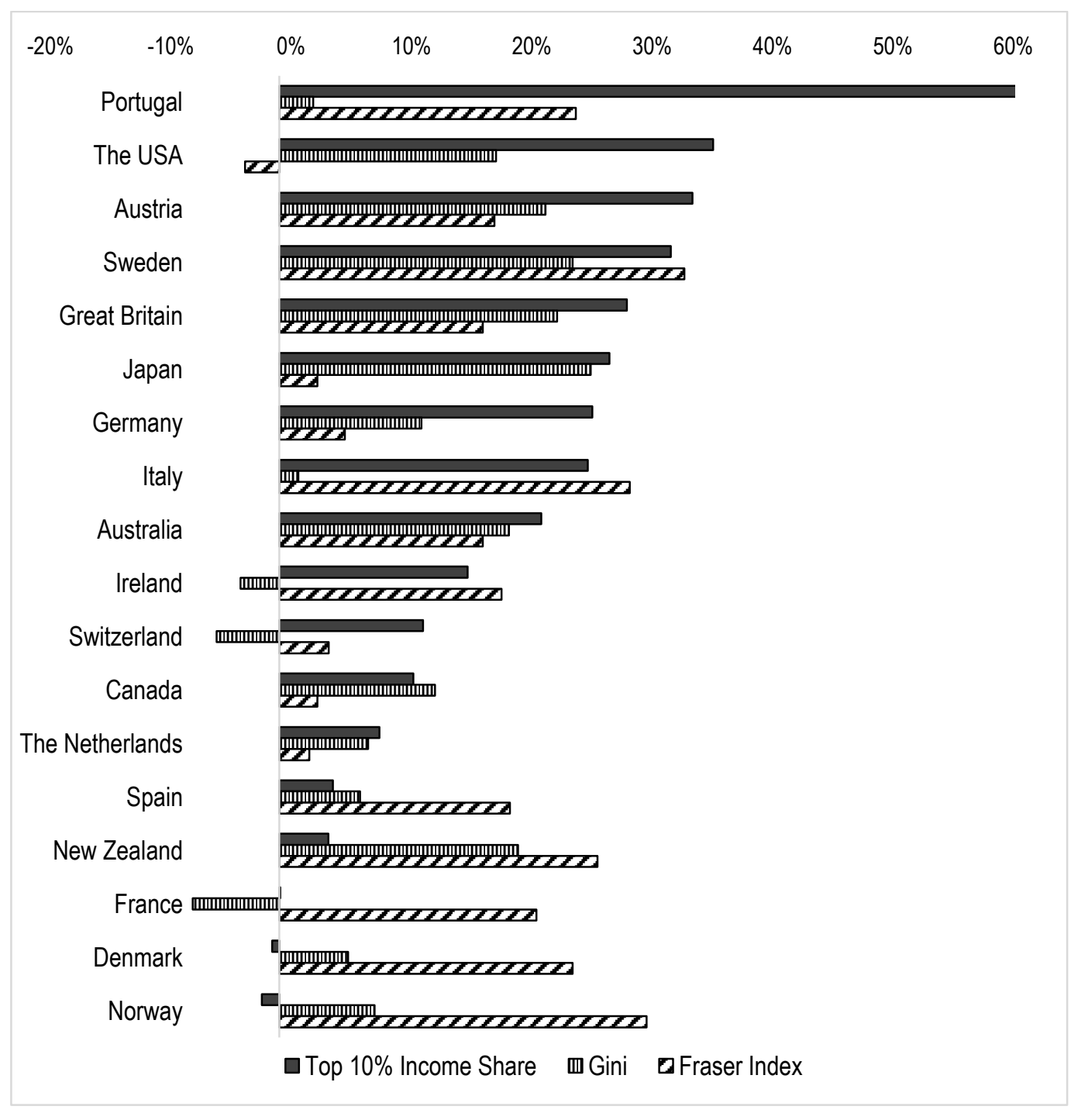

Figure 1. Income Inequality and Liberalization Change across Rich Democracies, 1980-2010

Figure 1 picks up in the time period after the 'golden age' of social welfare states (EspingAndersen 1996), after Keynesianism gave way to neoliberalism ${ }^{2}$ or what some label market fundamentalism (Gamble 2007; Weale 1990). To be clear, we are not arguing that liberalization and inequality are identical conceptually. The former relates to a changing degree of government socioeconomic intervention and the latter is purely an empirical measure of the distribution of income (or some other good). Our entire theoretical structure builds on liberalization as a cause of inequality. Thus, what we offer are measures of the results of reductions in government redistribution and provision of social welfare that cause increases in the economic freedom index and two measures of income inequality. With these measurements in mind, we see evidence in Figure 1 that 1980 through 2010 is an

\footnotetext{
${ }^{2}$ Liberalization in the late Twentieth Century is sometimes labeled 'neo-liberalization' to distinguish it from liberalization that took place preceding the industrial revolution when various monarchies and oligarchies (i.e., status and resources distributed based on birth/nobility) were replaced with more meritocratic market economies. Although this paper focuses on the rich welfare states of the world, liberalization is a global phenomenon (Stiglitz 2000).
} 
era of liberalization and income inequality on average. From top to bottom in Figure 1, income concentration took place among the top $10 \%$, in particular in Portugal, the US and Austria, and to a lesser degree in others. In France, Denmark and Norway, liberalization took place according to the Fraser index, but income concentration at the top did not increase. Therefore, we observe variation in the inequality and liberalization experience by country over time offering a basis for testing quasicounterfactual claims.

\section{Public Reaction}

Policies, or policy retrenchments, that harm a majority and disproportionately favor a small minority in terms of income and material security should be unpopular among the public (Rehm, Hacker, and Schlesinger 2012). The Great Recession and narratives about the decline of the middle class brought redistributive policies into the public sphere (DeLuca, Sean, and Ye 2012; Grisold and Theine 2017). For the first time in their industrialization histories, income, education, health and equality gains reversed in many rich democracies bringing the social solidarity and thus sustainability of entire societies into question (Chetty et al. 2017; Chiavacci and Hommerich 2017; Wilkinson and Pickett 2009).

We expect the public to have developed greater support for economic intervention to reduce income inequality after 1980; both out of self-interest and protection of collective resources (Soroka and Wlezien 2010). However, the degree that the public wants their national government to be the source of this intervention depends on public perception of governmental efficacy (Breznau 2010; Edlund 1999). Political efficacy is relatively high among rich democracies but depends a great deal on an individual's education level (Cicatiello, De Simone, and Gaeta 2016). Thus, net of education we expect rich democracies to be a site where citizens believe their governments are capable of handling social problems.

As liberalization's fallout harms the lowest socioeconomic status members of society most, there should be opposition among various working-classes who account for over $50 \%$ of many rich societies' populations (Gilbert 2014; Hertel 2017). At the same time there are higher status individuals who value equality and altruism and see instrumental reasons to support redistribution even against their own material self-interest (Breznau 2010), and when combined these strata should produce majorities in favor of redistribution under high levels of inequality (Fernández and Jaime-Castillo 2017; Huckfeldt, Plutzer, and Sprague 1993; Kulin and Meuleman 2015). This gives a simple data generating model of higher liberalization and inequality, and eventually a public shifting toward greater overall support of redistribution.

Therefore, we hypothesize: 
(H1) Public support of the government reducing income inequality increases as a function of inequality.

We consider "inequality" in $\mathrm{H} 1$ as inclusive of income inequality and one of its major causes as liberalization (the third indicator in Figure 1). If anything, this time period gives us a most likely case to observe attitude changes because 2010 lay directly in the wake of the economic collapse in the Great Recession.

Given material self-interest arguments (Dallinger 2010; Linos and West 2003) analogous to median-voter logic (Downs 1957), publics might fractionalize in their preferences as liberalization increases. Those toward the top of status hierarchy likely benefit from individual and corporate tax breaks, while those toward the bottom lose from retrenching redistributive and social insurance policies. As inequality increases, there are more and more individuals who would gain from government intervention into the distribution of income. This cleavage might lead to statistical suppression of an association in the entire population because the higher socioeconomic status individuals become less supportive of government intervention while the lower status individuals become more supportive, yet the average stays the same. We refer to socio-economic status rather than income strata because many individuals who have a high occupational status such as managers and high-level professionals might be temporarily unemployed and without income, but still be highly educated, skilled and quite secure in their future income and occupational prospects. Focusing on education and occupational status are therefore more reliable than income in identifying what an individual's preferences might be, not to mention the persistent missing data problem with income questions in surveys. Of course, theoretically, all three work together to define material interests or what some refer to as status and class (Ganzeboom, De Graaf, and Treiman 1992; Gugushvili, Bukodi, and Goldthorpe 2017). Therefore, we have a second hypothesis that:

(H2) Only among those in the lowest portion of the socio-economic hierarchy does support of the government reducing income inequality increase as a function of inequality.

We derive only two hypotheses predicting an increase in support for governmental redistribution. We do this intentionally as our larger research question is: why does inequality march forward in the present time period? We make the simple assumption that inequality will continue to increase unless the public in any given society starts to support governmental intervention in response to inequality. We are not aware of any other market actor that has the authority or purview of a national government to systematically decrease inequality. Therefore, we offer no alternative hypothesis, the null is simply that there is no inverse association with liberalization's effects and public preferences, i.e., an effect not statistically different from zero.

Many scholars provide arguments in favor of this null. The public may not react to inequality despite harms or, they may turn away from state redistribution as a solution. Work focused only on the 
United States by McCall and Kenworthy (2009) and Wright (2017) suggests that the public are concerned about rising inequality as theory expects, but do not systematically identify the government as the solution. In fact, the latter finds that after controlling for known confounding variables, the public are less supportive of government redistribution when more concerned about rising inequality. In parallel, attitudes toward earnings across the globe demonstrate that the public are satisfied with their societal income distributions, and without changing the pay structure income inequality by default does not change (Evans, Kelley, and Peoples 2010; Iversen and Soskice 2009; Kelley and Evans 1993). Moreover, there is a prevalence of negative attitudes toward the poor who are stigmatized as underserving (Buß, Ebbinghaus, and Naumann 2017; van Oorschot 2006; Steensland 2006). The public may struggle to form coherent preferences as they grapple with lack of information and default to negative stereotypes of those with lower incomes (Jacoby 2006; Petersen et al. 2011). This may be a product of racial, ethnic or culturally motivated attitudes against redistribution (Breznau and Eger 2016; Gilens 1996). Again, the null hypothesis is that public support of the government reducing income inequality has no association with liberalization. ${ }^{3}$

Theoretically we make strong claims that there should be an effect of liberalization and inequality on public opinion, but some previous research we review in the next section suggests mixed empirical results. In other words, there is existing evidence in favor of the null hypothesis. Relying solely on such evidence, we expect liberalization and inequality to march forth, further harming majorities of rich democratic societies. This would lead us to ask ourselves: is it possible that the effects of inequality are not negative enough to cause public reaction? Although things can always get worse, and individuals living in the rich democratic countries are generally better off than those in other countries, our review in the previous section presents serious problems associated with inequality. Problems that outweigh the arguments presented by neoliberal economists that inequality is a good thing (Friedman 2002; Mankiw 2013), especially as global productivity growth stagnated for decades and is likely to continue to decline through 2060 (OECD 2017b). Again, inequalities' problems relate to decreasing intergenerational elasticity of income, reductions in social mobility for those at the bottom of the status hierarchy, worsening public health, decreases in life expectancy and health for those lower in the income distribution, exacerbation of disadvantage by race, gender, sexuality and the intersections thereof, and much more (Grusky 2018: chapters 114-122 in particular). Therefore, supporting the null hypothesis here likely means that the public are not convinced that inequality is responsible for myriad social ills they face, that the government is not the solution, or they believe that they are responsible for their own situations. Given the many pathways through which the public might not react to inequality,

\footnotetext{
${ }^{3}$ This is a "null" hypothesis because it suggests that samples drawn from the same population over time will show no bivariate association with income inequality or economic freedom. It is null because our theory does not predict that liberalization has a zero causal effect on attitudes; for that we would need a "nil" hypothesis to which testing is beyond what is possible in this research.
} 
we do not make the null hypothesis a formal hypothesis, as we are unsure about the data generating model underlying it.

\section{State OF THE ART}

\subsection{Previous Research}

Our unit of observation is the public, defined as the population of a given country, and our hypotheses speak to public preferences for governmental redistribution varying or not within a given public. For this reason, we focus our literature review on studies of within-country variation in redistribution preferences ${ }^{4}$. Of previous within-country studies, two using European Social Survey (ESS) data identify a statistical impact of income inequality on support for redistribution (Jæger 2013; Schmidt-Catran 2016) while one study finds no overall support despite some unique country-specific associations (Gonthier 2017). Three studies using the International Social Survey Program (ISSP) find no striking evidence (Brady and Finnigan 2014; Kerr 2014; Kwon and Curran 2016). An alternative study by VanHeuvelen (2017) pools together ESS, ISSP 'Social Inequality' and ISSP 'Role of Government' modules to create the largest set of data points for analyzing this research question thus far, including 39 countries with up-to-18 time points per country. This innovative study finds no direct evidence of an association. VanHeuvelen and Copas (2018) follow this pooled survey strategy to additionally study the topic using a birth cohort design and again find no generalizable trends over time. These latter studies find what Kenworthy and McCall (2008) demonstrate visually using ISSP data: that there is no clear association.

The work of Schmidt-Catran (2016) ${ }^{5}$ and Jæger (2013) consider only the period 2002 through 2010, Kerr (2014) mostly from 1992 to 1999 and Brady and Finnigan (2014) from 1996 to 2006. Thus, each study observes a decade or less. In our study we have 1987 through 2010 for several countries and from 1992 through 2010 for nearly all. For most countries, liberalization and inequality increase slowly over two decades. Eight years or less may not be enough time for the effects of liberalization to manifest in the lives of individuals, families, the media and social networks in order to generate observable public preference shifts (see also mixed evidence by Kevins et al. 2018).

The work of Schmidt-Catran (2016) is extremely thorough methodologically, yet introduces two open questions. The first is what happened in the period before 2002. The second is what happened outside of Europe. Moreover, Schmidt-Catran includes Eastern European countries where the shock of

\footnotetext{
${ }^{4}$ Studies of between-country variance also shed light on the relationship of inequality and redistributive preferences (Alt and Iversen 2017; Dallinger 2010; Lübker 2004; Lupu and Pontusson 2011; Steele 2015). Theories of institutions and culture suggest unobserved heterogeneity between countries raising questions about fixed-slope models and leading us to focus on a within-country over-time perspective, i.e., random-slopes models (Castles 1993; Ebbinghaus 2005; Pfau-Effinger 2005; Wimmer and Feinstein 2010).
}

${ }^{5}$ See also Finseraas (2009). 
market transition sets up institutional contexts and values that may be entirely different regarding the role of the state and the evolution of preferences (Breznau 2010; Roller 1994). Schmidt-Catran also uses an income variable and this leads to a large number of missing cases. As income is presumed not to be missing at random this could produce a selection bias. The work of Jæger (2013) collapses individuals into an average of 26 socio-demographic groups per country, this shifts the analysis away from public opinion as a whole and moves it closer to an individual-level or group-specific measure of preferences. The work of Kerr (2014) uses log Gini, which emphasizes variance at the lower end of the distribution. Moreover, he does not directly observe within-country variance, only indirectly as a visualization in his Figure $1(\mathrm{C}$ and $\mathrm{D})$ revealing a positive slope for within-country changes in inequality, but without a significance test. Following these pioneering studies we see the possibility for improvement.

In terms of time points, VanHeuvelen's work is a major improvement over previous research with as many as 18 in some countries. Nonetheless, we are concerned that the diverging question wordings and sampling strategies in the data he combines introduces nesting or invariance problems, for example response heterogeneity to questions asking about general "differences in incomes" (ESS), differences between "high" and "low" incomes (one ISSP module) and differences between "rich and poor" (another ISSP module). His work remains path breaking and we want to follow it by focusing on additional instruments for investigating within-country trends.

\subsection{Endogeneity}

The highest levels of democratic functioning occur among rich democracies (Freedom House 2012). Therefore, the public in these rich democracies should have the largest possible role in influencing policymakers and policymaking. There are by now strong reasons to believe that opinion and policy are reciprocally causal (Breznau 2017; Campbell 2012; Soroka and Wlezien 2010). Given that policy shapes inequality, there is an endogenous link with opinion and inequality indirectly through policy or measures of liberalization (see also Weakliem, Andersen, and Heath 2005). It is no understatement to conclude that opinion and policy outcomes are intimately linked (Burstein 2003; Eger and Breznau 2017; Manza and Brooks 2012; Pierson 1993). Given some degree of opinion and policy reciprocity, there is a problem of endogeneity in statistical modeling of these two variables. In many cases, declaring either opinion or policy as the dependent variable and the other the independent variable is to commit a model misspecification (Breznau 2018). Some studies show that the statistical effect of inequality on attitudes exists only with the addition of a measure of government social spending (Schmidt-Catran 2016) or net redistribution (VanHeuvelen 2017). These results point toward this endogeneity.

Endogeneity comes in single variable trajectories as well. Attitude and opinion scholars regularly note the consistency of social policy preferences as linked to relatively stable institutions (norms, legal systems, culture, bureaucracy) in each society (Breznau 2010; Jæger 2006; Larsen 2008; 
Roller 1994). These arguments suggest path dependency (Pierson 1998), which leads to observation of variables with degrees of autocorrelation (Freeman, Williams, and Lin 1989). This is a problem that can easily bias regression estimates. Therefore, reciprocal causality and path dependency call for alternatives to unidirectional regression analysis, something we address in our empirical modeling strategies.

\section{EMPIRICAL DESIGN}

To test our hypotheses, we use comparative survey data from 18 rich democratic countries from the International Social Survey Program (ISSP) 'Social Inequality' and 'Environment' modules 6 , fielded between 1987 and 2010. These data capture a measure of support for redistribution in a large range of highly stable democratic societies over two decades or more in: Australia, Austria, Canada, Denmark, France, Germany (East and West) ${ }^{7}$, Ireland, Italy, Japan, The Netherlands, New Zealand, Norway, Portugal, Spain, Sweden, Switzerland, The United States and Great Britain, thus hereafter we speak of 19 'societies' for ease of discussion. Following our commitment to transparency, all replication materials and additional analyses are available via the Open Science Framework ${ }^{8}$. The period we discuss herein is 1980-2010 because this marked an unprecedented shift in policy and inequality increases characterizable as 'the neoliberal era'; however, we only have macro-comparative survey data starting in 1987, therefore our analyses cover 1987-2010.

\subsection{Measurement}

Our dependent variable is public opinion toward the role of government in reducing income inequality. The verbatim English in both 'Inequality' and 'Environment' modules reads, 'It is the responsibility of the government to reduce the differences in income between people with high incomes and those with low incomes." We use affirmative coding of response options: Strongly agree $=5$, agree $=4$, neither agree nor disagree $=3$, disagree $=2$ and strongly disagree $=1$. We label this variable Support_Redistribution. There are other forms of public opinion toward redistribution, for example believing that inequality is too high in general or the government should spend more on redistributive policies; however, these introduce confounding. The former does not ask what the government should do and the latter might face bias due to public perceptions of current spending level, whereas Support_Redistribution does not mention "more" or "spending" directly, thus minimizing these types of bias.

\footnotetext{
${ }^{6}$ Data downloaded from GESIS http://www.gesis.org/issp/. Countries that include data on all relevant variables listed in Figure 1.

${ }^{7}$ We split Germany to allow the starting point of the ISSP in 1987 to link to the 'same' parts of Germany over time.

${ }^{8}$ https://osf.io/gzsmb/
} 
Three macro-level independent variables provide tests for inequality/liberalization effects. The first, Top10 is the concentration of cumulative 'taxable' individual income split by couples, among the top $10 \%$ at the current time point using data from the World Inequality Database (WID 2018). This variable captures an entire population because it comes from tax records. The second is 'disposable' income inequality as the post-fiscal Gini after correcting for household equivalency (Solt 2016). This variable is the most commonly used in the history of income inequality research; however, it derives from survey data and therefore misses the richest individuals ${ }^{9}$. The third is the Fraser index measuring economic freedom in capital movement and accumulation ${ }^{10}$, thus it measures market liberalization (Kwon 2016). As secondary macro-level measures we use social spending on welfare state policies as a percentage of GDP 'SOCX' (OECD 2018), because the public might be normatively conditioned by the historical institutions of the welfare state or current policy outlays, loosely captured with spending. We use GDP at PPP in 2016 US\$ (OECD 2017a) because in times of higher productivity, spending tends to increase suggesting a positive image of redistribution in the public sphere (Wilensky 1975). Finally, we measure Counter, as years passed in each country ${ }^{11}$.

We use sample adjustments from individual-level independent variables, to correct compositional effects such as survey mode or timing of the sampling (Schmidt-Catran 2016; Sundberg and Taylor-Gooby 2013; Svallfors 1997). These include Age, dummy variable for Aged over 64, Female, Full-time employed, Education in years, and occupational status ISEI (Ganzeboom et al. 1992). We do a single stochastic imputation for ISEI using Age, Female and the within and between-components of Education and Support_Redistribution, plus a random number with mean $=0$ and s.d. $=8.5$ (similar to the observed s.d. of $I S E I$ ) to recover $17 \%$ missing data, we opt for imputation because we want to preserve the other relationships in the data while keeping the maximum number of responses to the redistribution question. As we collapse the data, multiple individual-level imputation is not necessary. The usage of individual-level variables only serves the purpose of correcting composition effects that result from diverging survey sampling methods in each country and sometimes across years. It accounts for randomnoise in any sample adjusting it to be as if 'all else' were equal (Raudenbush and Bryk 2002).

\subsection{Power}

The history of macro-comparative regression research is nearly void of power analyses. We want to know if we have the power to detect effects. Therefore, we select two delta scores for change in Support_Redistribution that reflect theoretically impactful scenarios. A change of 5\% of the sample into a one category higher response in the survey as more supportive of redistribution would reflect a small

\footnotetext{
${ }^{9}$ Gini is available for all countries, and we use this to impute Top10 as it is missing for Norway and Austria, see Online Supplement (link in footnote 8).

${ }^{10}$ https://www.fraserinstitute.org/

${ }^{11}$ For example, in Great Britain 1987=zero, 1992=five, 1993=six, 1999=12, 2000=13, $2009=22$ and 2010=23.
} 
but potentially relevant shift in public opinion. One that might swing the results of a close election. A change of $15 \%$ of the sample into one category higher would reflect a sweeping change, potentially changing mixed-support into a clear majority, see Online Appendix ${ }^{12}$. When these effects are standardized across 1987 to 2010, a close election swing (5\%) or full-blown public opinion shift (15\%) would reflect standardized effects of 0.202 and 0.606 respectively.

Table 1 reports power for these two effect sizes. The within-country samples range from twoto-seven time points (average $=$ five). We test alpha levels of 0.05 and 0.10 , given such small samples (alpha is analogous to a p-value cutoff). We test the power of a single slope and partial correlations with between one-and-four control variables at the country-time point level. These results give us a rough picture of the power available to detect an effect different from zero in a given country. We also have a random-effect power analysis, with 19 country-level cases, giving us the power to detect an "averageeffect" across all countries. Looking at the first row of Table 1, the likelihood of detecting a 5\% shift in Support_Redistribution $_{\mathrm{jk}}$ at an alpha 0.05 level in any one country ranges from 0.05 to 0.07 . While the power to detect a significant average effect across all random-slopes is 0.13 . On both fronts we have almost no power. There is a slim chance that we will detect a small shift. The likelihood of detection improves markedly when considering a larger shift of $15 \%$ and alpha of 0.10 , ranging from 0.15 to 0.40 and up to 0.51 for a partial correlation in the presence of one covariate for any single country. This also comes with a 0.70 (alpha of 0.05 ) and 0.81 (alpha of 0.10 ) likelihood of detecting an average-effect that is marginally different from zero. Best case, in the presence of a true effect in all 19 countries, we are only likely to detect it accurately in five out of 19 cases; however, taking a two-tailed approach we can imagine the remaining 12 cases as randomly splitting between under detecting, null findings and over detecting. This suggests that given a true effect and a random distribution of error, we should still see significant positive effects in (five plus four $=$ ) nine out of 19 countries.

We are under-powered, but these ISSP survey data are the most comprehensive in terms of coverage and the longest running time series available to measure Support_Redistribution. The works of Kerr (2014) and Brady and Finnigan (2014) use only two time points within countries. As shown in the first column of Table 1, this literally has no power to detect even a single regression slope. In terms of mean shifts in the population between time points, power is plentiful because of the thousands of respondents at the individual level in each country in the ISSP; however, these authors can only conclude that a shift in opinion is in the same direction as their independent inequality variables in betweencountry associations, but cannot statistically validate a causal model of within-country change, assuming correct model specification.

\footnotetext{
${ }^{12}$ Stata do-file "ineq5.do": https://osf.io/gzsmb/wiki/Analytical\%20Coding\%20\%26\%20Results/
} 


\begin{tabular}{|c|c|c|c|c|c|c|c|c|c|c|c|c|c|c|}
\hline \multirow[b]{3}{*}{$N=$} & \multicolumn{7}{|c|}{$5 \%$ shift in Support_Redistribution ${ }_{\mathrm{jk}}$} & \multicolumn{7}{|c|}{$15 \%$ shift in Support_Redistribution ${ }_{\mathrm{jk}}$} \\
\hline & \multicolumn{6}{|c|}{ within-country effect } & \multirow{2}{*}{$\begin{array}{c}\begin{array}{c}\text { average- } \\
\text { slope }\end{array} \\
19 \\
\end{array}$} & \multicolumn{6}{|c|}{ within-country effect } & \multirow{2}{*}{$\begin{array}{c}\begin{array}{c}\text { average- } \\
\text { slope }\end{array} \\
19 \\
\end{array}$} \\
\hline & 2 & 3 & 4 & 5 & 6 & 7 & & 2 & 3 & 4 & 5 & 6 & 7 & \\
\hline \multirow[t]{2}{*}{$\begin{array}{l}\text { single-slope, } \\
\text { alpha }=0.05 \\
\text { partial-correlation, } \\
\text { alpha }=0.05\end{array}$} & - & 0.05 & 0.06 & 0.06 & 0.07 & 0.07 & 0.13 & -- & 0.08 & 0.12 & 0.16 & 0.21 & 0.26 & 0.70 \\
\hline & -- & -- & 0.05 & 0.06 & 0.07 & 0.07 & 0.13 & -- & -- & 0.10 & 0.18 & 0.26 & 0.34 & 0.70 \\
\hline 2 covariates & -- & -- & -- & 0.06 & 0.06 & 0.07 & 0.13 & -- & -- & -- & 0.10 & 0.20 & 0.29 & 0.70 \\
\hline 3 covariates & -- & -- & -- & -- & 0.06 & 0.06 & 0.13 & -- & -- & -- & -- & 0.12 & 0.22 & 0.70 \\
\hline 4 covariates & -- & -- & -- & -- & -- & 0.06 & 0.13 & -- & -- & -- & -- & -- & 0.14 & 0.70 \\
\hline $\begin{array}{l}\text { single-slope, } \\
\text { alpha }=0.10 \\
\text { partial-correlation, } \\
\text { alpha }=0.10\end{array}$ & -- & 0.11 & 0.11 & 0.12 & 0.13 & 0.14 & 0.22 & -- & 0.15 & 0.22 & 0.28 & 0.34 & 0.40 & 0.81 \\
\hline 1 covariate & -- & -- & 0.11 & 0.12 & 0.13 & 0.14 & 0.22 & -- & -- & 0.20 & 0.32 & 0.42 & 0.51 & 0.81 \\
\hline 2 covariates & -- & -- & -- & 0.11 & 0.12 & 0.13 & 0.22 & -- & -- & -- & 0.22 & 0.35 & 0.47 & 0.81 \\
\hline 3 covariates & -- & -- & -- & -- & 0.11 & 0.13 & 0.22 & -- & -- & -- & -- & 0.23 & 0.39 & 0.81 \\
\hline 4 covariates & -- & -- & -- & -- & -- & 0.11 & 0.22 & -- & -- & -- & -- & -- & 0.25 & 0.81 \\
\hline $\begin{array}{l}\text { NOTE: } \mathrm{N}=2 \text { has no po } \\
\text { point higher level of su } \\
\text { country-time points, } 5 \\
\text { correlation diverge in }\end{array}$ & and & 0 dete & $\begin{array}{l}\text { t a slop } \\
\text { r calcu } \\
\text { ifts req } \\
\text { o differ }\end{array}$ & pe. " $\%$ & shifts" & $\begin{array}{l}\text { refer to } \\
\text { by sta } \\
\text { ized ef }\end{array}$ & $\begin{array}{l}\text { nd } 15 \% \text { c } \\
\text { rdizing the } \\
\text { sizes of } 0\end{array}$ & 2 & le cha & Idaring & heir su & $\begin{array}{l}\text { vey res } \\
\text { ns in o } \\
\text { slope a }\end{array}$ & $\begin{array}{l}\text { spons } \\
\text { ur san }\end{array}$ & $\begin{array}{l}\text { a one } \\
\text { e of }\end{array}$ \\
\hline
\end{tabular}

Table 1. Power Analyses for Within-Country Slopes and Average Random-Slope Across Countries

The study by Jæger (2013) has five time points per country but includes 7 country-level variables. As we see in Table 1, the power to detect a significant within-country slope disappears after adding three or more covariates, thus in regression analysis we must use two or less control variables at the country-time level to have any power. The work of Schmidt-Catran (2016) has up to five time points depending on the country with an average of three (calculated from his Table A2). In model M2 he has only the Gini as a country-time varying variable thus giving him roughly a power of 0.15 to detect a large effect. If we follow a similar design we will have nearly double the power at 0.28 (see Table 2, single-slope, 15\% shift, N=3 and 5 respectively). The VanHueleven (2017) study offers far more power theoretically given up to 18 time points per country, but the unorthodox procedure of merging together three different surveys with different question wordings suggests further research should validate his findings.

\subsection{Modelling}

We use three test strategies. First is multilevel regression modeling (MLM) following SchmidtCatran (2016). We focus our attention only on within-country variance germane to our two hypotheses. We control for composition effects and engage in country-centering to remove unobserved 
heterogeneity. We run sensitivity models only on populations scoring in the lower and upper ranges of the ISEI occupational status hierarchy and years of education (Ganzeboom et al. 1992). Although we are aware of better measures of educational attainment, these measures are less comparative and do not provide a distribution with easy cut points, and thus we settle for years (Ortmanns and Schneider 2016). Second, we consider reciprocal causality if not institutional path dependency in the autocorrelation of opinion and inequality. We thus run separate vector autoregressions (VAR) within each country. This allows us to test if inequality measures 'Granger cause' public preferences in a cross-lagged fashion (Freeman et al. 1989). Third, we use qualitative comparative analysis with fuzzy set logic (fsQCA) to identify if certain sets of conditions are necessary for us to observe a link of income inequality or liberalization with redistributive attitudes. Given the small sample size and the endogeneity of macrolevel variables, this method produces direct logical outcomes as to whether increases in inequality are a sufficient or necessary condition for increases in Support_Redistribution.

Our three pronged approach is further motivated by discussions among the open science movement (Breznau 2016; Gelman and Loken 2014; Munafò et al. 2017; Wuttke 2018). We are aware that when using a single class of methods, like regression-based techniques, it is easy to run thousands of models until something interesting appears; but running thousands of regressions is to entertain thousands of possible data generating models (Young 2018). In devising this study we wanted to test the data-generating model of inequality causing preferences. The data-generating model includes opinion-policy endogeneity and may have equifinality, two things we cannot deal with in unidirectional regression models. This explains our usage of feedback regression models and QCA, both are underutilized in social science vis-à-vis the workhorse unidirectional regression models.

\subsection{Descriptives and visualizations}

Table 2 offers our descriptive statistics at three levels with level-1, the within-country, betweentime variance on top as it is the level of our hypothesis tests. We introduce subscript letters for our variables for ease of reference where $i=$ individual, $j=$ country-time and $k=$ country. We have a threelevel model with individuals (level-0; subscript $i$ ) nested in country-times (level-1; $j$ ) in countries (level$2 ; k$ ). For our regression-based models, we want to make sure our variances are uniquely identified at each level. Our interest is only in the country-time variance; therefore, we do not add year randomintercepts. These would only be necessary if we were interested in correctly identifying between-country variance components without composition bias (Schmidt-Catran and Fairbrother 2016). 


\begin{tabular}{|c|c|c|c|c|c|}
\hline \multicolumn{6}{|c|}{ Within-Country/Between-Time Variance (level-1, N=91; our primary focus) } \\
\hline variable & measurement & mean & s.d. & $\min$ & $\max$ \\
\hline Support_Redistribution $_{j k}$ & $\begin{array}{l}\text { Government should reduce income } \\
\text { differences btw. rich and poor (ISSP, } 7 \\
\text { waves) }\end{array}$ & 0 & 0.14 & -0.34 & 0.29 \\
\hline Counter $_{j k}$ & Year starting at 0 for 1987 & 0 & 7.26 & -14.50 & 13.75 \\
\hline Top10jk & $\begin{array}{l}\text { Top } 10 \% \text { share of national income } \\
\text { distribution, taxable income split by couples, } \\
\text { pre-tax/transfer (WID 2017) }\end{array}$ & 0 & 0.02 & -0.04 & 0.05 \\
\hline Gini i $_{j k}$ & $\begin{array}{l}\text { Gini, post-tax/transfer household } \\
\text { equivalency, i.e., "disposable income" (Solt } \\
\text { 2016) }\end{array}$ & 0 & 0.01 & -0.03 & 0.02 \\
\hline Fraser $_{j k}$ & $\begin{array}{l}\text { Index of economic freedom (Fraser Institute } \\
\text { 2017) }\end{array}$ & 0 & 0.04 & -0.14 & 0.10 \\
\hline$S_{S O C X}$ & $\begin{array}{l}\text { Social welfare spending by the national } \\
\text { government as a \% of GDP (OECD 2018) }\end{array}$ & 0 & 2.16 & -5.20 & 4.84 \\
\hline$G D P_{j k}$ & $\begin{array}{l}\text { Gross domestic product per capita in } \\
\text { thousands of } 2015 \text { US\$ (OECD 2018) }\end{array}$ & 0 & 4.33 & -10.56 & 9.28 \\
\hline \multicolumn{6}{|c|}{ Between-Country Variance (level-2, N=19) } \\
\hline Support_Redistribution $_{k}$ & & 3.56 & 0.40 & 2.80 & 4.37 \\
\hline Counter $k_{k}$ & & 8.81 & 3.02 & 3.49 & 15.95 \\
\hline Income_Concentration $_{k}$ & & 0.32 & 0.06 & 0.21 & 0.41 \\
\hline Ginik & & 0.30 & 0.04 & 0.24 & 0.36 \\
\hline Fraser $_{k}$ & & 1.15 & 0.10 & 1.02 & 1.31 \\
\hline $\mathrm{SOCX}_{k}$ & & 22.18 & 4.86 & 15.14 & 31.13 \\
\hline$G D P_{k}$ & & 34.81 & 9.92 & 18.34 & 58.56 \\
\hline \multicolumn{6}{|c|}{ Total Variance, Individuals (level-0a $, \mathrm{N}=96,752$; used only for composition adjustments) } \\
\hline Support_Redistribution $_{i}$ & & 3.50 & 1.20 & 1 & 5 \\
\hline Age $_{i}$ & In years, leveled at 80 & 46.73 & 16.59 & 15 & 80 \\
\hline Female $_{i}$ & Female $=1 /$ male $=0$ & 0.52 & 0.50 & 0 & 1 \\
\hline Full $_{i}$ & Full-time employed & 0.44 & 0.50 & 0 & 1 \\
\hline $\begin{array}{l}\text { Education }_{i} \\
\text { ISEl }_{i}\end{array}$ & $\begin{array}{l}\text { In years, leveled at } 24 \\
\text { International SES Index of occupations } \\
\text { (Ganzeboom, de Graaf and Treiman 1992) }\end{array}$ & $\begin{array}{l}11.99 \\
44.42\end{array}$ & $\begin{array}{r}3.75 \\
15.54\end{array}$ & $\begin{array}{r}0 \\
16\end{array}$ & $\begin{array}{l}24 \\
90\end{array}$ \\
\hline
\end{tabular}

aWe have no interest in explaining variance at the individual level therefore we label it "level-0" and adjust only for composition effects before running two-level MLMs (at $j$ and k/levels 1 and 2)

Table 2. Measurement and Descriptive Statistics

We first decompose the variance of Support_Redistribution between individuals (88.6\% of total variance), country-time points (1.6\%) and countries (9.8\%) and then add independent individual-level variables. The independent variable effects (level-0) control for the part of attitudes explained by the 
sampling strategy and the distribution of socio-economic and demographic variables in each survey, i.e., composition effects that we then remove from our data. We then conduct our tests using only two levels, country (level-2) and country-time (level-1), now corrected for composition using predictive weighting (Hox and Kreft 1994; Schmidt-Catran 2016); however, we are only interested in the level-1 withincountry over-time variance. A common pitfall of macro-comparative research is to create spurious relationships by mixing variances at different levels (Kenworthy 2007).

The $1.6 \%$ of Support_Redistribution that occurs across years within countries is actually twofold more variance than the 0.7\% Schmidt-Catran (2016) identified in European Social Survey data. In either case, the ostensibly low values do not indicate 'little' variance (Schmidt-Catran 2016: 129). Considering that the standard deviation of Support_Redistribution $n_{j k}$ is 0.14 and in the overall sample it is 1.20 , the within-country variance of Support_Redistribution accounts for $(0.14 / 1.20=) 11.7 \%$ of the standard range of individuals' survey responses at level-1. If we take country-time points as a sample of some unobserved potential range of public preferences, then public 'mood' moves around about 0.14 points on the 5-point scale on average. This may sound like minimal movement, but imagine a scenario where average public support is " 3 " because one-third of the public are a " 2 " (disagree), one-third are a “3” out-of-5 (neutral) and one-third are a "4" (agree) out-of-5 in support for redistribution. If this shifted by 0.14 , keeping the neutral group at one-third, this would force the percent disagree from 33.33 down to 26.33 and the percent agree from 33.33 up to 40.33 . In terms of elections, this could mark a massive shift. For example, votes are often decided by a less than 5\% margin, and this is a shift of 14 percentage points 7 less disagreeing and 7 more agreeing.

We plot the within-country Support_Redistribution ${ }_{j k}$ variance against our independent variables after composition adjustment. The association of Support_Redistribution ${ }_{j k}$ with Top $10_{j k}$ (Figure 2), Gini ${ }_{j k}$ (Figure 3) and Fraser $_{j k}$ (Figure 4) is unclear with centered slopes running in every direction. There is however, a grand mean association that is positive in all three cases. This is not evidence that liberalization's various measures statistically predict Support_Redistribution $n_{j k}$, it merely reflects the average of all slopes. In each case the average is itself not significantly different from zero, this supports the null. A similarly ambiguous pattern emerges in bivariate time plots, see Figure 5. 


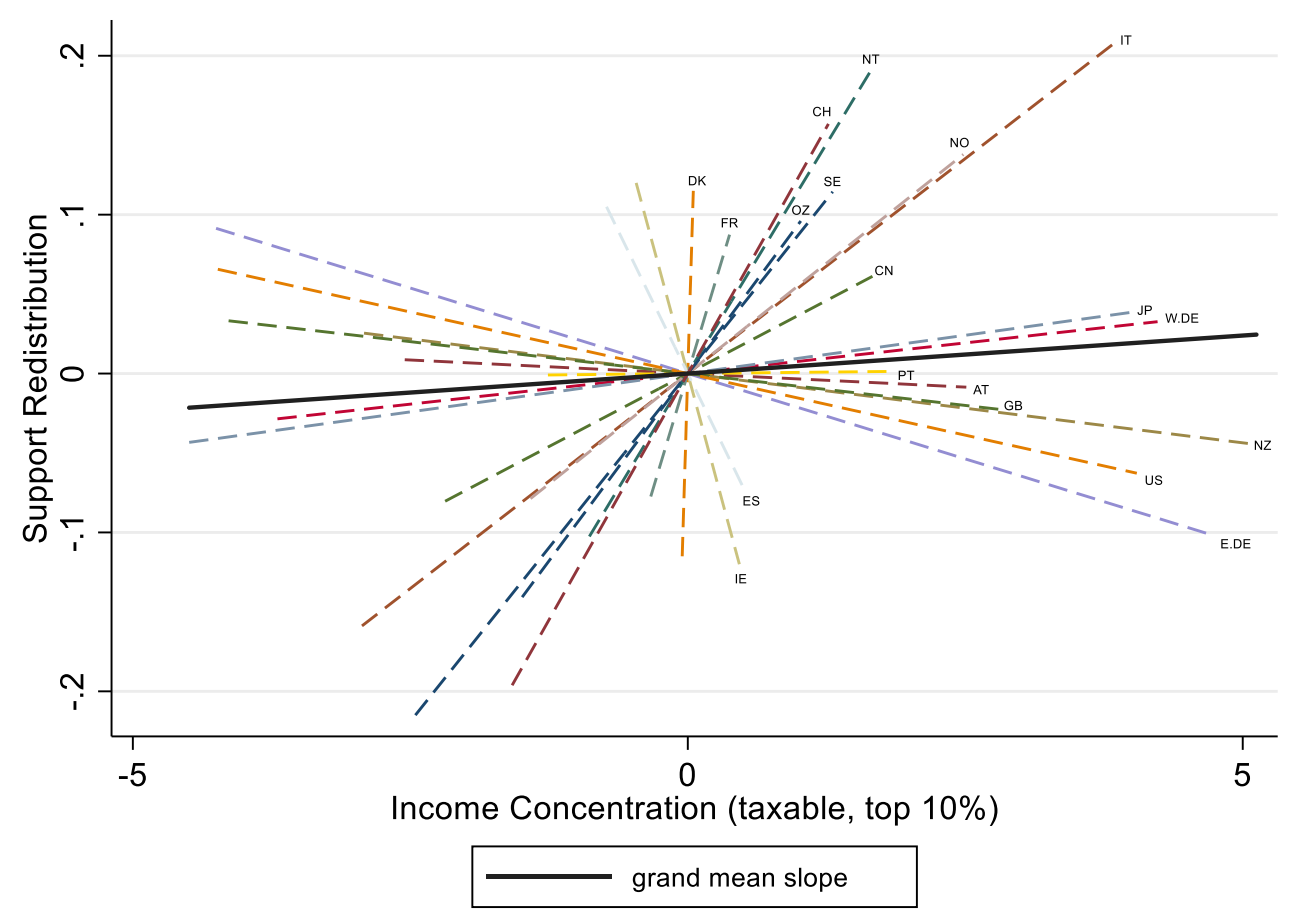

Figure 2. Within-Country Associations of Top10 and Support_Redistribution

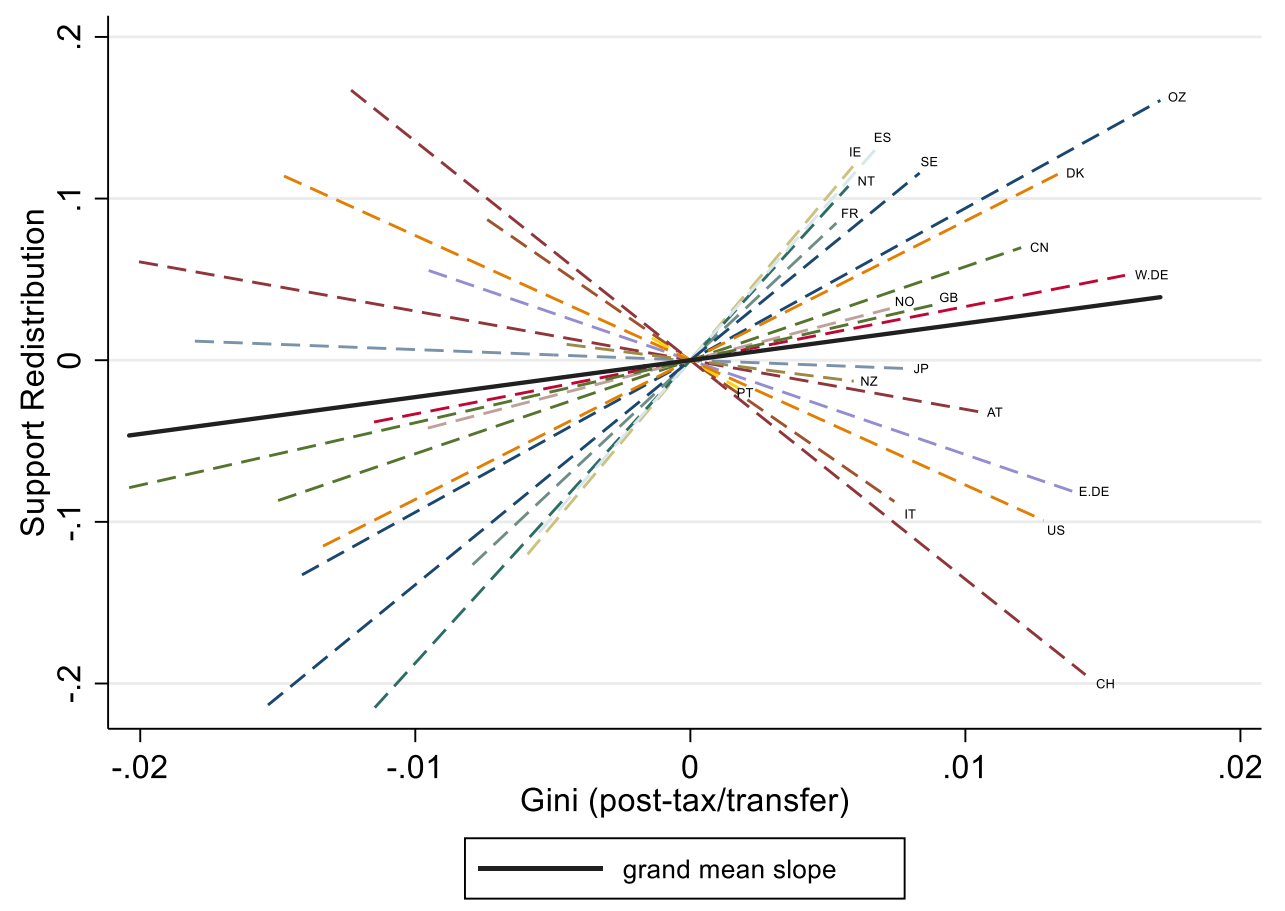

Figure 3. Within-Country Associations of Gini and Support_Redistribution 


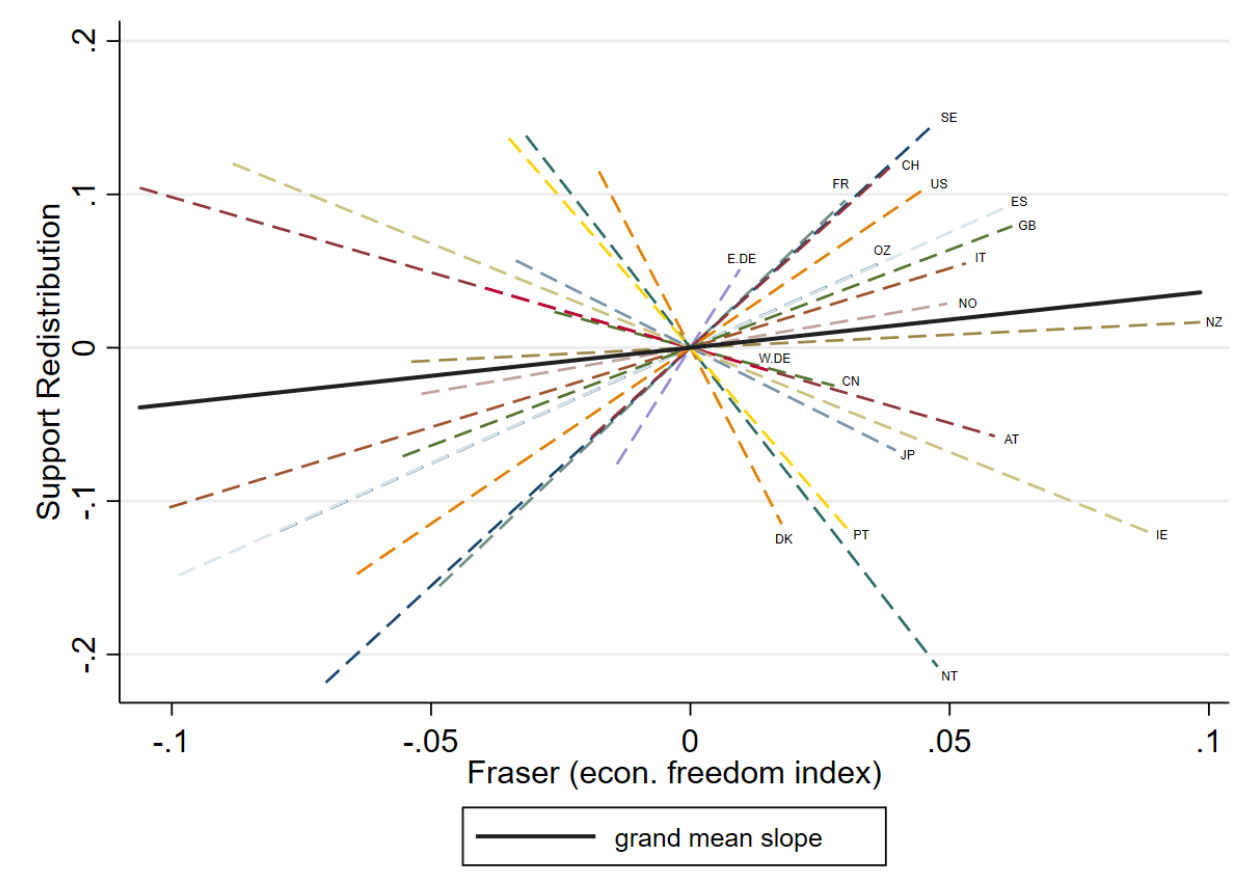

Figure 4. Within-Country Associations of Fraser and Support_Redistribution

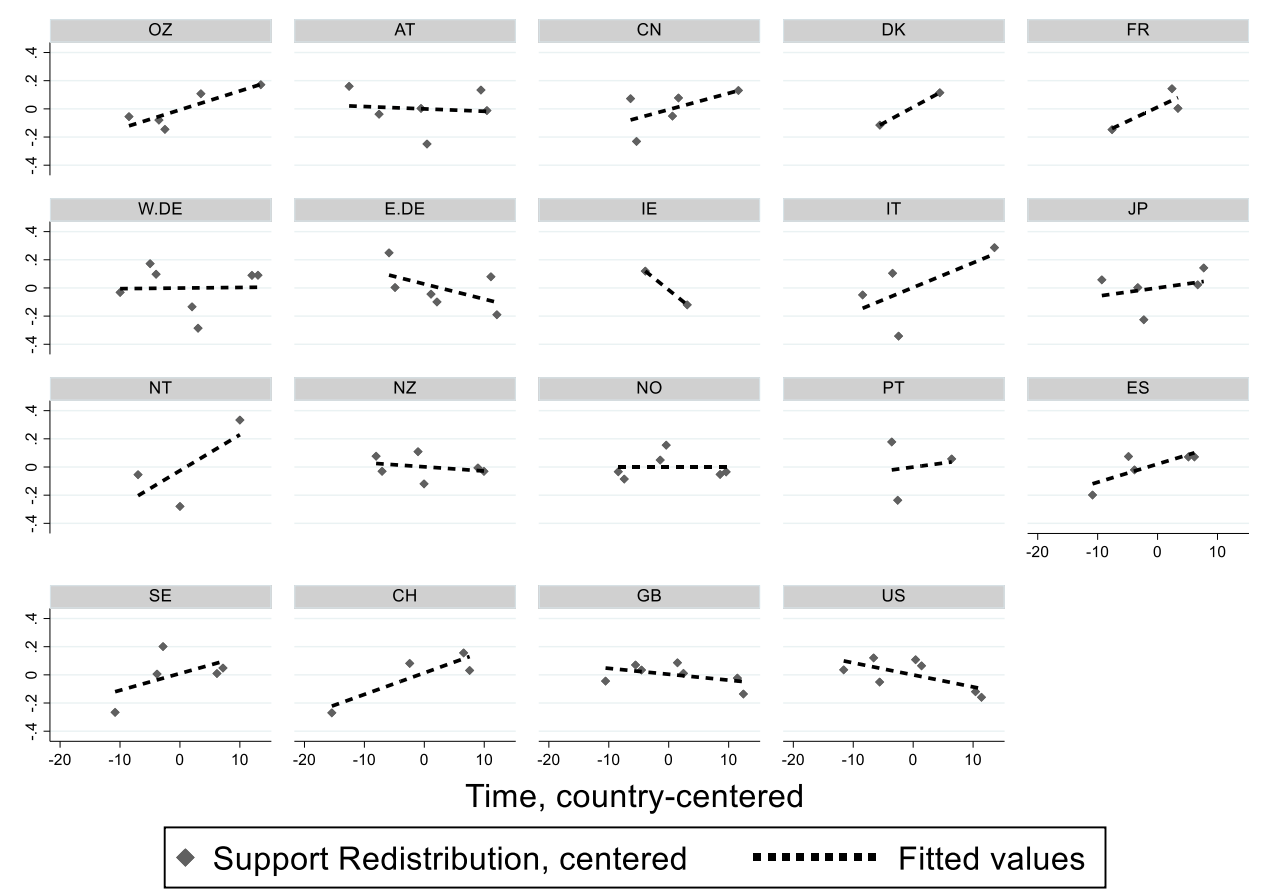

Figure 5. Within-Country Associations of Counter and Support_Redistribution 


\section{RESULTS}

\subsection{Multilevel regression modeling}

Some modeling notes: Table 3 (Appendix) reports results from an initial 3-level MLM predicting Support_Redistribution $i j k$ with Aged ${ }_{i}$, Aged $_{i}{ }^{2}$, Female $_{\mathrm{i}}$, Full $_{\mathrm{i}}$, Education $_{i}$, ISEI $_{\mathrm{i}}$ and randomintercepts at levels-1 and 2. This allows us to adjust Support_Redistribution ${ }_{i}$ for composition effects and simplify our analysis into two-level models focusing on level-1 (country-time) and level-2 (country), i.e., the change in Support_Redistribution ${ }_{j k}$ within-countries over time. We explore configurations of variables to rule out misspecifications and we multiply our three liberalization measures to make the results more intuitive as out-of-100 (times 100 for Top10 and Gini, and times 10 for Fraser).

With the model now simplified to two levels, we first run an empty-model to establish a baseline variance decomposition to which we compare subsequent models to asses improvement in fit (Hox 2010) (this is "M0" in Table 4). Then we add Counter $j$, and test whether each of the three centered liberalization measures shows a significant average ('fixed') within-country slope predicting Support_Redistribution $j$ in models with and without Counter rk $_{\text {. }}$ (M1-M7 in Table 4). Finally, we run each of models M1-M7 again with the addition of a random-slope for the corresponding liberalization variable (M8-M13, see "Random-portion" in Table 4). At the bottom of Table 4 we compare models on Akaike's and Bayesian Information Criteria (AIC/BIC) and likelihood ratio tests.

None of our three liberalization measures has a marginal value in a range that does not include zero, even at $\mathrm{p}<0.10$ (this refers to results in the rows for the coefficients B2, B3 and B4). The residual variance $(\sigma)$ decreases very little from the baseline M0 across all models and the AIC does not improve more than 3 points. More importantly, none of the likelihood ratio tests suggest that M1-M13 fit the data significantly better than M0. Given two models that do not fit significantly different, the smaller model is favored as it can explain the same things about the world with fewer variables, i.e., it is more parsimonious. This suggests that our MLM tests reject H1 and instead supports the null suggesting that there is no effect of inequality/liberalization measures on support for redistribution. The only evidence in favor of some models over others is a moderate decrease in BIC achieving its lowest point in M11 and M12. Without significant effects in these models, we reject them.

We are concerned that productivity or welfare state redistribution may bias our within-country results. As concluded in our power analysis we can enter a maximum of two within-country covariates with 5 time-points, but three or more moves power to zero. Therefore, we re-run the models in Table 4 with the addition of $G D P_{j k}$ and then $S O C X_{j k}$, see Table 5. Again, none of our inequality/liberalization measures are significant at $p<0.10$. The only effect that appears significant in any model is the betweencountry slope for Counter $j$. This might reflect a number of things, including a global period effect, but it certainly does not impact our results in or out of the models. 


\begin{tabular}{|c|c|c|c|c|c|c|c|c|c|c|c|c|c|c|c|}
\hline Component & & M0 & M1 & M2 & M3 & M4 & M5 & M6 & M7 & M8 & M9 & M10 & M11 & M12 & M13 \\
\hline \multicolumn{16}{|c|}{ Fixed-portion (mean of within-country slopes) $^{a}$} \\
\hline Counter $_{j k}$ & & -- & 0.004 & -- & -- & -- & 0.005 & 0.004 & 0.004 & -- & -- & -- & 0.005 & 0.004 & 0.004 \\
\hline Top10 jk & [B2] & -- & -- & 0.005 & -- & -- & -0.007 & -- & -- & 0.007 & -- & -- & -0.007 & -- & -- \\
\hline Gini $_{j k}$ & [B3] & -- & -- & -- & 0.018 & -- & -- & -0.004 & -- & -- & 0.022 & -- & -- & 0.001 & -- \\
\hline Frasier $_{j k}$ & [B4] & -- & -- & -- & -- & 0.029 & -- & -- & 0.012 & -- & -- & 0.031 & -- & -- & 0.004 \\
\hline constant & [B0] & $4.274^{*}$ & $4.274^{*}$ & $4.274^{*}$ & $4.274^{*}$ & $4.274^{*}$ & $4.274^{*}$ & $4.274^{\star}$ & $4.274^{*}$ & $4.274^{*}$ & $4.275^{\star}$ & $4.275^{*}$ & $4.274^{*}$ & $4.274^{\star}$ & $4.274^{*}$ \\
\hline residual & $\sigma$ & 0.023 & 0.022 & 0.022 & 0.022 & 0.022 & 0.022 & 0.022 & 0.022 & 0.022 & 0.022 & 0.021 & 0.022 & 0.021 & 0.020 \\
\hline \multicolumn{16}{|c|}{ Random-portion (unique effect for each country) ${ }^{a}$} \\
\hline & $\mathrm{B} 2_{\mathrm{k}} \sigma$ & -- & -- & -- & -- & -- & -- & -- & -- & 0.000 & -- & -- & 0.000 & -- & -- \\
\hline & $B 3_{k} \sigma$ & -- & -- & -- & -- & -- & -- & -- & -- & -- & 0.001 & -- & -- & 0.000 & -- \\
\hline & $B 4_{k} \sigma$ & -- & -- & -- & -- & -- & -- & -- & -- & -- & -- & 0.010 & -- & -- & 0.011 \\
\hline & $\mathrm{B}_{\mathrm{k}} \sigma$ & 0.115 & 0.116 & 0.116 & 0.116 & 0.116 & 0.116 & 0.116 & 0.116 & 0.116 & 0.116 & 0.116 & 0.116 & 0.116 & 0.116 \\
\hline
\end{tabular}

Model comparisons

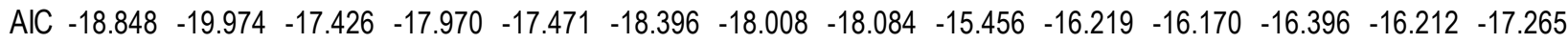

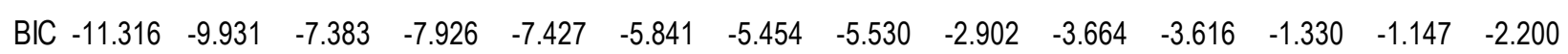

LR tests

\begin{tabular}{lcccccccccccccc} 
M0 & -- & 0.077 & 0.447 & 0.290 & 0.430 & 0.170 & 0.206 & 0.198 & 0.738 & 0.504 & 0.516 & 0.315 & 0.339 & 0.220 \\
M1 & -- & -- & -- & -- & -- & 0.516 & 0.855 & 0.740 & -- & -- & - & 0.810 & 0.888 & 0.525 \\
M2 & -- & -- & -- & - & -- & 0.085 & -- & -- & 0.863 & - & - & 0.227 & -- & -- \\
M3 & -- & -- & -- & -- & -- & -- & 0.153 & -- & -- & 0.618 & - & - & 0.326 & \\
M4 & -- & -- & -- & -- & -- & -- & -- & 0.106 & -- & - & 0.403 & - & - & 0.150 \\
M5 & -- & -- & -- & -- & -- & -- & -- & -- & -- & -- & - & 1.000 & - & - \\
M6 & -- & -- & -- & -- & -- & -- & -- & -- & -- & -- & - & - & 0.652 & - \\
M7 & -- & -- & -- & -- & -- & -- & -- & -- & -- & -- & - & -- & -- & 0.277 \\
\hline
\end{tabular}

${ }^{*} p<.05$; observations $=91$ country-years in 19 countries; Random-portion average 5 cases per country (range 3 to 7 )

${ }^{a}$ All variables country centered consistent with our within-country hypotheses; variances ( $\sigma$ ) reported for B1-B4 from random slopes of the corresponding fixed-portion variables and for BO from random-intercepts (what some precariously refer to as "country fixed-effects").

bikelihood Ratio Test that there is significant difference between the row and column models.

Table 4. Multilevel Models predicting the Within-Country Variance of Support for Redistribution 


\begin{tabular}{|c|c|c|c|c|c|c|c|c|c|c|c|}
\hline Component & & M0 & M14 & M15 & M16 & M17 & M18 & M19 & M20 & M21 & M22 \\
\hline \multicolumn{12}{|c|}{ Fixed-portion (mean of within-country slopes) ${ }^{a}$} \\
\hline Counter $_{j k}$ & & -- & -- & -- & -- & $0.010^{*}$ & $0.009^{*}$ & $0.009^{*}$ & $0.017^{*}$ & $0.016^{*}$ & $0.015^{*}$ \\
\hline Top10 jk & [B2] & -- & 0.002 & -- & -- & -0.007 & -- & -- & -0.006 & -- & -- \\
\hline $\operatorname{Gini}_{j k}$ & [B3] & -- & -- & 0.015 & -- & -- & -0.000 & -- & -- & -0.005 & -- \\
\hline Frasier $_{j k}$ & [B4] & -- & -- & -- & 0.012 & -- & -- & 0.038 & -- & -- & 0.032 \\
\hline$G D P_{j k}$ & [B5] & -- & 0.004 & 0.003 & 0.005 & -0.008 & -0.009 & -0.010 & $-0.018^{*}$ & $-0.018^{*}$ & -0.018 \\
\hline$S O C X_{j k}$ & [B6] & -- & -- & -- & -- & -- & -- & -- & -0.016 & -0.015 & -0.013 \\
\hline constant & [BO] & $4.274^{*}$ & $4.275^{\star}$ & $4.275^{\star}$ & $4.275^{\star}$ & $4.273^{*}$ & $4.273^{\star}$ & $4.274^{*}$ & $4.272^{*}$ & $4.272^{*}$ & $4.273^{*}$ \\
\hline residual & $\sigma$ & 0.023 & 0.022 & 0.021 & 0.020 & 0.021 & 0.020 & 0.020 & 0.021 & 0.020 & 0.020 \\
\hline \multicolumn{12}{|c|}{ Random-portion (variance of unique effect by country) ${ }^{a}$} \\
\hline & $\mathrm{B} 2_{\mathrm{k}} \sigma$ & -- & 0.000 & -- & -- & 0.000 & -- & -- & 0.000 & -- & -- \\
\hline & $\mathrm{B}_{\mathrm{k}} \sigma$ & -- & -- & 0.001 & -- & -- & 0.001 & -- & -- & 0.001 & -- \\
\hline & $B 4_{k} \sigma$ & -- & -- & -- & 0.014 & -- & -- & 0.008 & -- & -- & 0.004 \\
\hline & $\mathrm{B} 5_{\mathrm{k}} \sigma$ & -- & 0.000 & 0.000 & 0.000 & 0.000 & 0.000 & 0.000 & 0.000 & 0.000 & 0.000 \\
\hline & $\mathrm{B} 6_{\mathrm{k}} \sigma$ & -- & -- & -- & -- & -- & -- & -- & 0.000 & 0.000 & 0.000 \\
\hline & $\mathrm{BO}_{\mathrm{k}} \sigma$ & 0.115 & 0.116 & 0.116 & 0.116 & 0.116 & 0.117 & 0.117 & 0.117 & 0.117 & 0.117 \\
\hline \multicolumn{12}{|c|}{ Model comparisons } \\
\hline & AlC & -18.848 & -12.493 & -12.841 & -15.900 & -21.865 & -15.773 & -16.682 & -21.731 & -21.347 & -21.784 \\
\hline & $\mathrm{BIC}$ & -11.316 & 5.083 & 4.735 & -0.835 & -11.821 & 1.803 & 0.894 & -9.176 & -8.792 & -9.229 \\
\hline LR te & st v. M0 & -- & 0.860 & 0.798 & 0.437 & 0.031 & 0.332 & 0.240 & 0.038 & 0.046 & 0.037 \\
\hline \multicolumn{12}{|c|}{${ }^{*} p<.05 ;$ observations $=91$ country-years in 19 countries; Random-portion average 5 cases per country (range 3 to 7 ) } \\
\hline \multicolumn{12}{|c|}{$\begin{array}{l}\text { aVariables centered to test within-country hypotheses; variances }(\sigma) \text { reported for } B 1-B 6 \text { from random slopes of the } \\
\text { corresponding fixed-portion variables and for } B 0 \text { from random-intercepts (what some precariously refer to as "country fixed- } \\
\text { effects"). }\end{array}$} \\
\hline \multicolumn{12}{|c|}{ bikelihood Ratio Test that there is significant difference between the row and column models. } \\
\hline
\end{tabular}

Table 5. MLMs predicting Within-Country Variance of Support for Redistribution, with Covariates

Given that the culture of social science encourages researchers to search for significance, we expect readers to imagine Type II errors (Gelman and Loken 2014; Wicherts et al. 2016). We therefore run three sensitivity analyses to help insulate against such claims. For the first test, we run a model with measures of Gini and Top10 logged, the second is a model without adjustment for sampling or composition effects, i.e., just the raw country-time point averages from the samples. Third, we run a model correlating the within-country random slopes with political efficacy borrowed from the Role of Government ISSP module. We find no evidence of an association, which we otherwise would have see if perceptions of the effectiveness of government were suppressing our attempts to test H1. These results are available in Table 6 in the Online Appendix ${ }^{13}$. In all cases we arrive at the same results that are visually obvious in Figures 2-4 as rejection of $\mathrm{H} 1$ and support of the null.

\footnotetext{
${ }^{13}$ https://osf.io/gzsmb/wiki/Main\%20Results/
} 


\subsection{Vector autoregression}

Next we use VAR to account for the autocorrelation of Support_Redistribution ${ }_{j k}$ over-time within the 12 countries that have at least 5 time-points. Although we remove the between-country covariance attributable to different institutional contexts in our MLM by centering and then allowing random-slopes, this procedure does not account for the incorporation of previous preference change on later preference levels nor the reciprocal causality of preferences and inequality as a result of policy within countries. Therefore, the level of Support_Redistribution ${ }_{j k}$ at any given time point is a product of previous shocks or changes in Support_Redistribution $j$, and allowing it to act as a lagged variable predicting a later version of itself removes potential confounding that might result. What remains after correcting for autocorrelation are actual changes beyond the path dependency of public preferences, and what some call "Granger causality" although this does not speak to causal inference nor offers confirmation of causality (Granger 1969; Stock and Watson 2001).

Using VAR to treat public opinion series as path dependent allows us to adjust for an unknown length of causal lag. We have no explicit theory of how many years it takes for inequality changes to cause public preferences changes, nor how many years a change retains a lasting impact on later levels of preferences (see for example Breznau 2018). Employing VAR allows us to rule out a range of crosslagged and autoregressive effects in testing $\mathrm{H} 1$ and the null. In other words, it gives us a closer approximation of a theoretical model of public opinion and policy outcomes as a reciprocal feedback loop with path dependency (Pierson 2000a; Soroka and Wlezien 2010).

We cannot look at the varying effect of different variable lag lengths because the samples are unbalanced and the waves somewhat sporadic; however, one lag captures the previous trajectory of public opinion and the gap between captures the change of both opinion and inequality/liberalization measures, that is if changes exist over the gap. Table 7 presents the results, and shows that in only nine out of 36 regressions does a lagged liberalization measure have a significant statistical effect on Support_Redistribution $_{\mathrm{jk}}$ at time $t$. Of those nine significant coefficients, only two of them show a positive effect consistent with our predictions in $\mathrm{H} 1$, the other seven show negative effects contrary to both $\mathrm{H} 1$ and the null. However, the main conclusion from the upper panel is no consistent effect of inequality/liberalization measures - evidence against $\mathrm{H} 1$. 


\begin{tabular}{|c|c|c|c|c|c|c|}
\hline \multicolumn{7}{|l|}{ Support_Redistribution $_{t}(\mathrm{DV})$} \\
\hline regressed on: & $\mathrm{DV}_{\mathrm{t}-1}$ & Top10 & $D V_{t-1}$ & $\operatorname{Gini}_{t-1}$ & $D V_{t-1}$ & Frasier $_{t-1}$ \\
\hline$\overline{O Z}$ - Australia & 0.101 & 0.104 & -0.078 & 0.135 & 0.352 & 0.145 \\
\hline AT - Austria & -0.393 & 0.009 & -0.418 & -0.008 & -0.369 & 0.013 \\
\hline $\mathrm{CN}$ - Canada & -0.271 & $0.095^{\star}$ & $-0.436^{*}$ & $0.129 *$ & -0.232 & 0.471 \\
\hline W.DE - Germany(W) & 0.142 & -0.001 & 0.138 & 0.007 & 0.100 & -0.384 \\
\hline E.DE - Germany(E) & -0.274 & $-0.021 *$ & -0.147 & $-0.080 *$ & 0.058 & $1.432^{*}$ \\
\hline JP - Japan & -0.063 & 0.023 & -0.004 & 0.027 & 0.041 & 0.163 \\
\hline NZ - New Zealand & $-0.743^{*}$ & -0.013 & $-0.629^{*}$ & -0.086 & $-0.483^{*}$ & $-0.074^{*}$ \\
\hline NO - Norway & -0.975 & 0.071 & -0.060 & 0.015 & -0.193 & 0.108 \\
\hline ES - Spain & -0.145 & 0.030 & -0.279 & 0.054 & -0.366 & 0.047 \\
\hline SE - Sweden & 0.192 & -0.020 & 0.040 & 0.002 & 3.586 & -1.405 \\
\hline GB - Great Britain & 0.483 & $-0.027^{*}$ & $1.415^{*}$ & $-0.069 *$ & 0.785 & -0.086 \\
\hline US - United States & -0.039 & -0.023 & -0.294 & $-0.108^{*}$ & 0.057 & 0.084 \\
\hline \multicolumn{7}{|l|}{ [inequality measure] ${ }_{t}$ regressed } \\
\hline on: & $\mathrm{DV}_{\mathrm{t}-1}$ & Top10 & $\mathrm{DV}_{\mathrm{t}-1}$ & $\operatorname{Gini}_{t-1}$ & $D V_{t-1}$ & Frasier $_{t-1}$ \\
\hline$\overline{\mathrm{OZ} \text { - Australia }}$ & -0.953 & $0.637^{\star}$ & 0.920 & $1.043^{*}$ & -0.045 & 0.248 \\
\hline AT - Austria & -2.680 & $0.838^{*}$ & -1.887 & 0.306 & -0.374 & $0.536^{*}$ \\
\hline CN - Canada & $-5.241^{*}$ & $0.740^{*}$ & $-5.518^{*}$ & $0.875^{*}$ & $0.516^{*}$ & $-1.599^{*}$ \\
\hline W.DE - Germany(W) & $-7.581^{*}$ & $0.797^{*}$ & $-2.917^{*}$ & $0.973^{*}$ & 0.052 & -0.060 \\
\hline E.DE - Germany(E) & $-10.341^{*}$ & $0.799^{*}$ & -3.116 & $0.866 *$ & 0.227 & 0.758 \\
\hline JP - Japan & $-15.043^{*}$ & $0.535^{\star}$ & -1.147 & $0.262^{*}$ & -0.440 & $-0.672^{*}$ \\
\hline NZ - New Zealand & $32.454^{*}$ & 0.505 & 2.092 & 0.276 & -0.076 & 0.090 \\
\hline NO - Norway & -3.122 & 0.370 & 0.816 & $0.600 *$ & 0.223 & 0.080 \\
\hline ES - Spain & 0.084 & 0.488 & $5.588^{*}$ & -2.384 & $1.982^{*}$ & -0.155 \\
\hline SE - Sweden & $2.753^{*}$ & $0.235^{\star}$ & 0.170 & $0.488^{*}$ & 3.773 & -1.358 \\
\hline GB - Great Britain & 0.022 & $0.686^{*}$ & $7.524^{*}$ & -0.102 & $6.502^{*}$ & -0.432 \\
\hline US - United States & 1.480 & $0.776^{*}$ & -0.580 & $0.685^{*}$ & 2.508 & 0.030 \\
\hline
\end{tabular}

Table 7. Vector Autoregression Coefficients, 12 Countries with at least Five Waves of ISSP Data 


\subsection{Qualitative comparative analysis using fuzzy sets}

Perhaps our regressions failed to capture the complexities of inequality or liberalization's impact on Support_Redistribution because there are heterogeneous sets of conditions to produce such an effect. Therefore, we turn to fsQCA (Ragin 1987). This allows us to test sets of variables, and to identify if in any sets the presence of increased inequality is sufficient or necessary to bring about an increase in Support_Redistribution $\mathrm{j}_{\mathrm{jk}}$. Moreover, we gain the advantage of equifinality where there can be several solutions to an outcome. This offers something regression to the mean cannot. For example, in countries where the positive gains of economic growth outpace the detriments of liberalization, we might not expect the public to demonstrate higher Support_Redistribution ${ }_{\mathrm{jk}}$ unless social spending also goes down substantially; whereas social spending going down significantly might not lead to increases in inequality because of economic stagnation (Hirschman and Rothschild 1973).

Our fuzzy-set analysis focuses only on within-country change: the " $j k$ " subscripted variables in Table 1 . To quantify within-country change we center the variables and linearly transform them to a minimum of 0 and maximum of 1 . As variables approach 1 , they approach the highest within-country values of each variable. As they approach 0 , they are at the lowest within-country levels. Thus, a Support_Redistribution $_{\mathrm{jk}}$ score above 0.5 represents an increased score on redistribution relative to the mean, while below 0.5 is a decrease. Values close to 0.5 represent stability (i.e., remaining near the mean). We use the clustering option to account for the non-independence of observations over-time within each country. In our first model, "FQ1" we leave in all three inequality/liberalization measures as they each capture a different part of liberalization and its outcomes.

The results of FQ1 show several common sets, none of which contain Top10 and only eight out of 91 cases appear in the common sets. We drop Top10 given that it measures something very close to Gini and is not necessary for the outcome. In doing so, we are left with our two common sets and eight cases in FQ2. We consider that Fraser might measure liberalizations that do not have immediate consequences. Therefore, to give our test the greatest chance to find support of H1, we remove Fraser and focus only on income inequality which is an outcome already realized in part as a result of liberalization. Results in FQ3 show that every independent variable's incidence is among sets leading to the outcome. Therefore, our common sets are not particularly unique, containing no necessary or sufficient variables or configurations thereof, see Online Appendix, "Sensitivity Test"14.

In carefully considering each observation, East Germany stands out. For one, attitudes toward redistribution consistently decreased since the end of socialism. Eastern Germany's historical institutions motivated a shift away from redistribution going away from a socialized/centralized economy (Roller 1994). These may bias what we try to capture in an effect of inequality on redistribution attitudes. Thus, to clean up our fuzzy-set analysis and further investigate a Type II error we re-run models FQ1-FQ3 with East Germany dropped (FQ4-FQ6). We consider these results our main findings;

\footnotetext{
${ }^{14}$ https://osf.io/gzsmb/wiki/Sensitivity\%20Tests/
} 
however, none of them support H1, neither alone nor in combination with other variables, see Table 8 (Appendix). Finally, we make a new dataset where we only code positive change in Support_Redistribution $_{\mathrm{jk}}$ as 1 and everything else as 0 , and results find no common sets and are even worse than before. To summarize the problem, we present the 14 cases belonging to the common set CNFPS in model FQ3 in Table 9. This is the only set that might explain an increase in Support_Redistribution $_{\mathrm{jk}}$ as it contains all cases with an increase in $\operatorname{ToplO}_{\mathrm{jk}}(\mathrm{C}), \operatorname{Gini}_{\mathrm{jk}}(\mathrm{N}), \operatorname{Fraser}_{\mathrm{jk}}(\mathrm{F})$, $G D P_{\mathrm{jk}}(\mathrm{P})$ and $S O C X_{\mathrm{jk}}(\mathrm{S})$. Although in almost all cases the Gini stayed about average (0.5) or increased, Support_Redistribution $_{\mathrm{jk}}$ showed both increased levels (above 0.5) and decreased levels (below 0.5). There is no pattern here, and this is just additional evidence on top of no sufficient or necessary conditions.

To demonstrate the lack of effect of liberalization in any format on Support_Redistribution ${ }_{\mathrm{jk}}$ we finally list the coincidence rates by variable and set in Table 10 (Appendix). Every variable occurs in sets where the outcome $(\mathrm{G})$ also occurs at a standardized rate at or above 0.8 after rounding. This suggests that there is no special variable in the list. The common set CNFPS suggests that the occurrence of every variable is a common set that produces the outcome and 14 observations best fit to this set. The CNFPS set has a high coincidence of 0.9 ; however, all other sets, including those without best fits have a similarly high coincidence rate. There are no common sets with a high number of best fitting cases that stand out, everything occurs with the outcome. Put simply, there is no rhyme or reason to inequality or liberalization increases or lack thereof in any combination of variables in producing the outcome. We fail to support $\mathrm{H} 1$ and use this as arguments that it is not due to Type II error. 


\begin{tabular}{|c|c|c|c|c|c|c|c|}
\hline Country & Year & $\begin{array}{c}\text { Support_ } \\
\text { Redistribution }_{\mathrm{jk}}\end{array}$ & $\operatorname{Top} 90_{\mathrm{jk}}(\mathrm{C})$ & $\operatorname{Gini}_{\mathrm{jk}}(\mathbf{N})$ & $\operatorname{Frasier}_{\mathrm{jk}}(\mathrm{F})$ & $\mathrm{GDP}_{\mathrm{jk}}(\mathbf{P})$ & $\operatorname{SOCX}_{\mathrm{jk}}(\mathbf{S})$ \\
\hline US & 2010 & 0.3 & 0.7 & 0.5 & 0.3 & 0.8 & 0.9 \\
\hline W.DE & 1999 & 0.3 & 0.7 & 0.8 & 0.4 & 0.9 & 0.8 \\
\hline US & 2009 & 0.3 & 0.9 & 0.6 & 0.4 & 0.8 & 0.8 \\
\hline UK & 2009 & 0.5 & 0.8 & 0.8 & 0.5 & 0.8 & 0.9 \\
\hline AT & 2010 & 0.5 & 0.7 & 1.0 & 0.8 & 0.8 & 0.8 \\
\hline NT & 2009 & 0.5 & 0.2 & 0.5 & 0.5 & 0.7 & 0.6 \\
\hline $\mathrm{FR}$ & 2010 & 0.5 & 0.4 & 0.6 & 0.7 & 0.6 & 0.6 \\
\hline$J P$ & 2009 & 0.5 & 0.9 & 0.7 & 0.5 & 0.6 & 0.9 \\
\hline NO & 1999 & 0.6 & 0.6 & 0.6 & 0.8 & 0.6 & 0.5 \\
\hline PT & 2009 & 0.6 & 0.7 & 0.7 & 0.4 & 0.6 & 1.0 \\
\hline ES & 2009 & 0.6 & 0.5 & 0.7 & 0.7 & 0.7 & 0.8 \\
\hline ES & 2010 & 0.6 & 0.4 & 0.7 & 0.7 & 0.7 & 0.9 \\
\hline W.DE & 2009 & 0.6 & 0.9 & 0.7 & 0.6 & 0.7 & 0.7 \\
\hline W.DE & 2010 & 0.6 & 0.9 & 0.9 & 0.6 & 0.8 & 0.6 \\
\hline $\mathrm{OZ}$ & 1999 & 0.7 & 0.6 & 0.6 & 0.7 & 0.7 & 0.6 \\
\hline AT & 2009 & 0.7 & 0.7 & 1.0 & 0.9 & 0.8 & 0.8 \\
\hline FR & 2009 & 0.7 & 0.5 & 0.6 & 0.7 & 0.6 & 0.6 \\
\hline$J P$ & 2010 & 0.7 & 0.8 & 0.7 & 0.5 & 0.6 & 1.0 \\
\hline $\mathrm{CH}$ & 2009 & 0.7 & 0.6 & 0.5 & 0.5 & 0.7 & 0.7 \\
\hline $\mathrm{OZ}$ & 2009 & 0.8 & 0.6 & 1.0 & 0.7 & 1.0 & 0.7 \\
\hline IT & 2009 & 0.9 & 0.9 & 0.6 & 0.9 & 0.7 & 0.9 \\
\hline NT & 2010 & 1.0 & 0.6 & 0.7 & 0.4 & 0.8 & 0.6 \\
\hline \multicolumn{8}{|c|}{$\begin{array}{l}\text { NOTE: Single common set after fsQCA of the outcome Support_Redistribution by N, P and S (in bold). Variables measured } \\
\text { only on their wihtin-country, over time variance such that } 0.5 \text { is the mean of each variable in each country and values } \\
\text { approaching } 1 \text { suggest increases in support for redistribution. Earlier models reveal NPS is parsimonious, but all models } \\
\text { (CNFPS and NFPS included) provide no sufficient or necessary examples, even with an extrememly fuzy interpretation of } \\
\text { results. When we dichotomize variables into positive, negative or no change, there are no common sets; see Online Appendix. }\end{array}$} \\
\hline
\end{tabular}




\subsection{SES Cleavage}

For a senstivity test of $\mathrm{H} 1$ and to aim at controlling Type II error in our MLMs from section 5.1, we consider an attitudinal gap between higher and lower SES strata (H2). We use ISEI scores of 39 and under and years of education of 11 and under to identify a low SES category. This allows us to rule out any participation in tertiary education and includes all manual laborers skilled and unskilled. It includes street vendors, housekeeping, hairdressing, cleaning, farming, and blue-collar labor with skills but in lower positions as assistants or aides (i.e., without higher incomes and educational qualifications). We use ISEI scores at 45 and up and education years at 12 and up to identify a high SES category. Professions with an ISEI score of above 45 are increasingly knowledge intensive or consistently calling for higher education and are especially prone to higher incomes (Ganzeboom et al. 1992). The range in between we drop as it is unclear if they are knowledge or manual labor intensive, and to make sure we get a cleavage in socioeconomic status for investigation.

We first consider the bivariate associations of our three inequality/liberalization measures and Support_Redistribution ${ }_{j k}$, similar to Figures 2-4; however, we are interested in whether the slopes go in different directions for low and high SES sub-groups so we conduct Wald slope-comparison tests and report them in Table 11 (Appendix). The bivariate, unstandardized slopes comparing the three inequality/liberalization measures with Support_Redistribution ${ }_{j k}$ are only significantly different between low and high SES strata in three cases using our Wald test. To account for the small number of cases we use an adjusted Wald test with standard errors halved, and this extremely liberal test reveals only 18 out of 57 are significant (eight for Top10, four for Gini, and seven for Fraser, see Table 11 column "W."). Even the simple Counter variable has only six out of 19 significant differences between low and high SES. This might be partial evidence of H1 if the low SES had positive slopes and the high SES neutral or negative slopes, but this is not what we find. Of the 18 significantly different slopes, 10 of them show lower SES individuals having a significant reduction in Support_Redistribution ${ }_{j k}$ relative to high SES.

Next, we follow a similar MLM process where we correct for composition effects and then focus only on within-country variance of Support_Redistribution $n_{j k}$. Table 12 reports the fixed and random-slopes as well as the significance tests of the various models. In Table 12 none of the withincountry fixed-slopes (B2, B3 and B4) are significant except for M8 for high SES. Overall, this is strong evidence against an SES suppression effect postulated in $\mathrm{H} 2$ and further evidence against $\mathrm{H} 1$. 


\begin{tabular}{|c|c|c|c|c|c|c|c|}
\hline \multicolumn{8}{|c|}{ Low SES $($ ISEI $<39 \&$ Education $<12)$} \\
\hline & & M2_lo & M3_lo & M4_lo & M8_lo & M9_lo & M10_lo \\
\hline \multicolumn{8}{|l|}{ Fixed-portion } \\
\hline$T_{o p 10} j k$ & [B2] & -0.000 & -- & -- & -0.000 & -- & -- \\
\hline $\operatorname{Gini}_{j k}$ & [B3] & -- & 0.012 & -- & -- & 0.018 & -- \\
\hline Frasier $_{j k}$ & [B4] & -- & -- & -0.005 & -- & -- & -0.010 \\
\hline \multicolumn{8}{|c|}{ Random-portion } \\
\hline & $\mathrm{B} 2_{\mathrm{k}} \sigma$ & -- & -- & -- & 0.000 & -- & -- \\
\hline & $\mathrm{B} 3_{\mathrm{k}} \sigma$ & -- & -- & -- & -- & 0.001 & -- \\
\hline & $B 4_{k} \sigma$ & - & - & -- & -- & - & 0.026 \\
\hline \multicolumn{8}{|c|}{ High SES $\quad(|S E|>44 \&$ Education $>11)$} \\
\hline & & m2_hi & m3_hi & m4_hi & m8_hi & m9_hi & m10_hi \\
\hline \multicolumn{8}{|l|}{ Fixed-portion } \\
\hline$T_{o p 10_{j k}}$ & [B2] & 0.010 & -- & -- & $0.030^{*}$ & -- & -- \\
\hline $\operatorname{Gini}_{j k}$ & [B3] & -- & 0.023 & -- & -- & 0.025 & -- \\
\hline Frasier $_{j k}$ & [B4] & -- & -- & 0.067 & -- & -- & 0.067 \\
\hline \multicolumn{8}{|c|}{ Random-portion } \\
\hline & $\mathrm{B} 2_{\mathrm{k}} \sigma$ & -- & -- & -- & 0.001 & -- & -- \\
\hline & $\mathrm{B} 3_{\mathrm{k}} \sigma$ & - & -- & -- & -- & 0.002 & -- \\
\hline & $\mathrm{B} 4_{\mathrm{k}} \sigma$ & -- & -- & -- & -- & -- & 0.000 \\
\hline
\end{tabular}

Table 12. Multilevel Coefficients for Support for Redistribution on Liberalization Measures by Low and High SES Categories 


\section{Conclusion}

Our overall results reject the hypothesis that inequality or liberalization increases support for redistribution among rich democratic welfare states (H1). Using multilevel models, vector autoregressions and fuzzy set qualitative comparative analysis we find neither statistical effects nor sufficient or necessary conditions of three different income inequality and liberalization measures for within-country changes in public support for redistribution. This is a triple rejection of $\mathrm{H} 1$. We rule out some potential Type II errors by investigating within-country changes, and further test the sensitivity of these in lower and higher socioeconomic strata separately and using raw rather than composition adjusted-data. We find no association leading to a rejection of $\mathrm{H} 2$. We thus have support of the null hypothesis, something visually apparent in Figures 2 through 4.

Results from some previous studies of within-country income inequality and redistribution attitude linkages already pointed us in this direction; nonetheless, our power analyses, our implementation of a longer time-series, and alternative techniques of VAR and fsQCA suggest that our findings are improvements on and more reliable than previous research. These findings are a compliment to the pioneering work of VanHeuleven (2017) whose study has the power both in case numbers and in time span to identify an insignificant effect. The weakness is potential divergences in survey respondents understanding of the questions or reactions based on different survey modes. We also see our additional tests as expanding on his findings as he only used unidirectional regression analyses and VAR and QCA have the potential to overcome some endogeneity bias. Our findings are, however, surprising theoretically. Access to material resources and insurance against social risks for large segments of the public worsened both in absolute and relative terms in rich democratic societies from 1980-2010, but public opinion changed in no systematic way in response. For us, this explains why inequality rose during the early 2000 s and offers a predictive insight into the future. As long as preferences do not change, inequality will likely continue rising - this is the primary conclusion of this work.

This is not to say that our research closes the curtain on this topic. Our power analysis is a sobering wake up call for all of macro-comparative quantitative research. Our within-country power is only as high as 0.51 , and revealed that we should see 9 out of 19 cases demonstrating a positive effect of liberalization, given low power and random-error. For H1, only between 4 and 7 effects are significant and positive. To further expand previous work and account for theoretical reciprocal causality of opinion and policy within-countries we engaged in vector autoregression. However, here we again suffer from low power. Therefore, research upon further rounds of ISSP data are necessary; this means continued funding of the ISSP in respective countries which is ironically uncertain under liberalization of governments. Given the often long periods of time in between ISSP surveys, new ideas on how to engage in macro-comparative study would help move the field forward, e.g., ideas like using QCA or historical path tracing in a meta-format. Moreover, alternative approaches that consider values or experiences of social mobility might hold some missing pieces to the data-generating model, although both are very 
difficult to measure free of dependent variable endogeneity (values) or objective parental data (social mobility in the ISSP) (Fatke 2018; Steele 2015). Finally, there is the perennial issue of this ISSP question's pluralistic attitude objects. It potentially taps attitudes toward government intervention in general, evaluations of the level of inequality, dislike and envy of the rich and concern for the poor, leaving a degree of uncertainty in the measurement of attitudes that cannot be overcome with a single survey question (Cavaillé and Trump 2015), although we prefer this question over all others as it does not mention spending or ideal levels of equality. Thus, further research is necessary to determine how much responses of the public to a question on, "the responsibility of government to reduce differences in incomes" is actually operational or is merely a symbolic or normative position (Ellis and Stimson 2012). In other words, more research should test if this ISSP question is a strong predictor of preferences that the government make new laws, spend more money and (further) institutionalize redistribution.

Assuming the question does cognitively reflect its face value of asking about the government reducing incomes, we speculate why we do not find an effect. Other research suggests that support for social welfare policies increases in some contexts as a result of liberalization and increasing income inequality (Breznau and Hommerich 2019; Lupu and Pontusson 2011). However, as previous research on policy preferences suggests, support of the social welfare state and attitudes toward income redistribution are different attitude objects. The public find it easier to favor government subsidies, care for old persons, health care and unemployment insurance as opposed to direct income redistribution (Berens 2015; Breznau 2010; Coughlin 1980; Papadakis and Bean 1993; Svallfors 1997; Wade 2012). Those who see the poor as undeserving, are likely to oppose increasing their incomes, and vice-versa (Gilens 1995; Jacoby 2000; van Oorschot 2000; Petersen et al. 2011). Even those working in occupations directed at helping the poor or those facing greater social risks tend to have anti-redistributive, neoliberal preferences demonstrating deeply entrenched normative values against 'handouts' (Kane 2017).

Mass media may be a source of strong bias against the government being an appropriate solution to inequality (Bartels 1986; Bendz 2015; Patashnik and Zelizer 2013; Pierson 1996; Soss and Schram 2007). The usurpation of the public sphere by private media allows those with lots of capital to control the media and send messages of persuasion to the public; messages including those that shift the focus away from income inequality or at least the government doing anything about it. A softer version of this argument is that the public prefer to hear messages framing both the government and the 'poor' negatively, thus the media tailors itself to public demand. For example Barnes and Hicks (2018) demonstrate that the type of media consumed covaries with individual austerity preferences, suggesting that media might be a fixture in the invariance of public opinion over time. It is also possible that mass media simply distracts the public from experiencing attitude formation in response to top income concentration and liberalization.

As a result of the media and street-level experiences, the public may experience subjectively heightened group boundaries, in particular along ethnic-racial and religious-cultural lines. The sustained or increasing diversity of all rich democratic welfare states during the 1990s and into the new millennium 
is a key factor in deservingness perceptions and welfare state chauvinism leading to decreased support for redistribution (Eger and Breznau 2017; Gilens 2009; Schmidt-Catran and Spies 2016). A formal model by Alt and Iversen (2017) considers differences in relative risk across income and immigrant groups as conditioning the impact of income inequality on preferences for government redistribution. Although this highlights the group-based process behind preference formation, it cannot account for the null hypothesis in this study. There remains so systematic change in preferences corresponding with income inequality, and we speculate this is a primary reason inequality continues to rise.

It is also possible that immigration interacts with negative deservingness perceptions based on theories of group threat, leading to a suppression of the otherwise expected global increase in support for redistribution (Bay and Pedersen 2006). Scholars of welfare state and redistributive attitudes point out that class cleavages lost their significance in advanced democratic welfare states. These traditional cleavages between lower SES and higher SES voters, are now replaced by political cleavages between left, right and new populist parties (Edlund and Lindh 2015; Gingrich and Häusermann 2015). This means that those who are hit hardest by liberalization are not likely to band together in public opinion supporting government redistribution, but instead blame the poor, immigrants and center-left political parties.

The findings lead us to expect inequality to continue its march forward among rich democracies if not worldwide. The same persons being harmed by inequality via a reduction of social insurance or risk pooling as policies liberalize, are reluctant to support government redistribution. These are exactly the strata of society that would need to become politically and socially active to support government taking a role in redistribution to see changes. Grusky ${ }^{15}$ points out in reference to the US case that equality is marketized. Children need preschool, childcare, primary and secondary schooling, test prep courses and safe neighborhoods to have equal chances at social mobility. Liberalization reduces governmental assistance in providing these things, and chances for equality of income, occupation and welfare are increasingly privately determined by income. These are generalizable phenomena to any country with liberalization, although the US educational system might be an extreme case. This is a vicious cycle and allows for continued increases in inequality, and our results suggest that public opinion will not deter it, especially given that research shows income inequality reduces electoral turnout (Stockemer, LaMontagne, and Scruggs 2012). Assuming the state is the only actor with the legitimacy and purview to intervene in this cycle, our findings suggest that public opinion will continue to 'allow' the state to liberalize.

\footnotetext{
${ }^{15}$ In his keynote delivered to the RC28, 'Research in Stratification and Mobility' Annual Meeting, Seoul, Korea, 2018 (and in all of his recent and forthcoming work).
} 


\section{REFERENCES}

Alt, James and Torben Iversen. 2017. "Inequality, Labor Market Segmentation, and Preferences for Redistribution.” American Journal of Political Science 61(1):21-36.

Alvaredo, Facundo, Lucas Chancel, Thomas Piketty, Emmanuel Saez, and Gabriel Zucman. 2017. Global Inequality Dynamics: New Findings from WID. WORLD. w23119. Cambridge, MA.

Barnes, Lucy and Timothy Hicks. 2018. "Making Austerity Popular: The Media and Mass Attitudes toward Fiscal Policy." American Journal of Political Science 0(0).

Bartels, Larry M. 1986. "Issue Voting Under Uncertainty: An Empirical Test." American Journal of Political Science 30(4):709-28.

Bay, Ann-Helén and Axel West Pedersen. 2006. "The Limits of Social Solidarity: Basic Income, Immigration and the Legitimacy of the Universal Welfare State." Acta Sociologica 49(4):419-36.

Beller, E. and M. Hout. 2006. "Welfare States and Social Mobility: How Educational and Social Policy May Affect Cross-National Differences in the Association between Occupational Origins and Destinations." Research in Social Stratification and Mobility 24,(4):333-412.

Bendz, Anna. 2015. "Paying Attention to Politics: Public Responsiveness and Welfare Policy Change." Policy Studies Journal 43(3):309-32.

Berens, Sarah. 2015. "Between Exclusion and Calculating Solidarity? Preferences for Private versus Public Welfare Provision and the Size of the Informal Sector." Socio-Economic Review.

Bergh, Andreas. 2005. "On the Counterfactual Problem of Welfare State Research: How Can We Measure Redistribution?” European Sociological Review 21(4):345-57.

Brady, David and Ryan Finnigan. 2014. "Does Immigration Undermine Public Support for Social Policy?” American Sociological Review 79(1):17-42.

Breznau, Nate. 2010. "Economic Equality and Social Welfare: Policy Preferences in Five Nations.” International Journal of Public Opinion Research 22(4):458-84.

Breznau, Nate. 2016. "Secondary Observer Effects: Idiosyncratic Errors in Small-N Secondary Data Analysis.” International Journal of Social Research Methodology 19(3):301-18.

Breznau, Nate. 2017. "Positive Returns and Equilibrium: Simultaneous Feedback Between Public Opinion and Social Policy.” Policy Studies Journal 45(4):583-612.

Breznau, Nate. 2018. "Simultaneous Feedback Models with Macro-Comparative CrossSectional Data." Methods, Data, Analyses 12(2):265-308.

Breznau, Nate and Maureen A. Eger. 2016. "Immigrant Presence, Group Boundaries, and Support for the Welfare State in Western European Societies.” Acta Sociologica 59(3):195-214.

Breznau, Nate and Carola Hommerich. 2019. "The Limits of Inequality: Public Support for Social Policy Across Rich Democracies.” International Journal of Social Welfare forthcoming.

Burstein, Paul. 2003. "The Impact of Public Opinion on Public Policy: A Review and an Agenda." Political Research Quarterly 56(1):29-40. 
Buß, Christopher, Bernhard Ebbinghaus, and Elias Naumann. 2017. "Making Deservingness of the Unemployed Conditional: Changes in Public Support for the Conditionality of Unemployment Benefits." P. 167 in The Social Legitimacy of Targeted Welfare: Attitudes to Welfare Deservingness. New York: Edward Elgar Publishing.

Campbell, Andrea Louise. 2012. "Policy Makes Mass Politics.” Annual Review of Political Science 15(1):333-51.

Castles, Francis G. 1993. Families of Nations: Patterns of Public Policy in Western Democracies. Hanover, NH, NH: Dartmouth University Press.

Cavaillé, Charlotte and Kris-Stella Trump. 2015. "The Two Facets of Social Policy Preferences." The Journal of Politics 77(1):146-60.

Chetty, Raj, David Grusky, Maximilian Hell, Nathaniel Hendren, Robert Manduca, and Jimmy Narang. 2017. "The Fading American Dream: Trends in Absolute Income Mobility Since 1940.” Science 356(28 April):398-406.

Chiavacci, David and Carola Hommerich. 2017. "After the Banquet: New Inequalities and Their Perception in Japan since the 1990s." Pp. 3-26 in Social Inequality in Post-Growth Japan: Transformation during Economic and Demographic Stagnation, edited by D. Chiavacci and C. Hommerich. London and New York: Routledge.

Cicatiello, Lorenzo, Elina De Simone, and Giuseppe Lucio Gaeta. 2016. “Cross-Country Heterogeneity in Government Transparency and Citizens' Political Efficacy: A Multilevel Empirical Analysis." Administration \& Society 50(4):595-623.

Corak, Miles. 2013. "Income Inequality, Equality of Opportunity, and Intergenerational Mobility." The Journal of Economic Perspectives 27(3):79-102.

Coughlin, Richard. 1980. Ideology, Public Opinion and Welfare Policy: Attitudes toward Taxes and Spending in Industrialized Societies. Berkeley: University of California Press.

Dallinger, Ursula. 2010. "Public Support for Redistribution: What Explains Cross-National Differences?" Journal of European Social Policy 20(4):333-49.

DeLuca, Kevin M., Lawson Sean, and Sun Ye. 2012. "Occupy Wall Street on the Public Screens of Social Media: The Many Framings of the Birth of a Protest Movement." Communication, Culture \& Critique 5(4):483-509.

Downs, Anthony. 1957. An Economic Theory of Democracy. New York: Harper and Row.

Ebbinghaus, Bernhard. 2005. "When Less Is More: Selection Problems in Large-N and SmallN Cross-National Comparisons.” International Sociology 20(2):133-52.

Edlund, Jonas. 1999. "Trust in Government and Welfare Regimes: Attitudes to Redistribution and Financial Cheating in the USA and Norway." European Journal of Political Research 35(3):341-70.

Edlund, Jonas and Arvid Lindh. 2015. "The Democratic Class Struggle Revisited: The Welfare State, Social Cohesion and Political Conflict.” Acta Sociologica 58(4):311-28.

Eger, Maureen A. and Nate Breznau. 2017. "Immigration and the Welfare State: A CrossRegional Analysis of European Welfare Attitudes.” International Journal of Comparative Sociology 58(5):440-63.

Ellis, Christopher and James A. Stimson. 2012. Ideology in America. New York: Cambridge University Press.

Esping-Andersen, Gøsta. 1996. "After the Golden Age? Welfare State Dilemmas in a Global Economy." Pp. 1-31 in Welfare States in Transition: National Adaptations in Global Economies. Thousand Oaks, CA: Sage Publications. 
Evans, M. D. R., Jonathan Kelley, and Clayton D. Peoples. 2010. "Justifications of Inequality: The Normative Basis of Pay Differentials in 31 Nations." Social Science Quarterly 91(5):1405-31.

Fatke, Matthias. 2018. "Inequality Perceptions, Preferences Conducive to Redistribution, and the Conditioning Role of Social Position." Societies 8(4).

Fernández, Juan J. and Antonio M. Jaime-Castillo. 2017. "The Institutional Foundation of Social Class Differences in Pro-Redistribution Attitudes: A Cross-National Analysis, 1985-2010." Social Forces 1-30.

Finseraas, Henning. 2009. "Income Inequality and Demand for Redistribution: A Multilevel Analysis of European Public Opinion.” Scandinavian Political Studies 32(1):94-119.

Freeman, John R., John T. Williams, and Tse-min Lin. 1989. "Vector Autoregression and the Study of Politics.” American Journal of Political Science 33(4):842-77.

Friedman, Milton. 2002. Capitalism and Freedom: Fortieth Anniversary Edition. Chicago: University of Chicago Press.

Gamble, Andrew. 2007. "Neoliberalism.” Pp. 3175-78 in The Blackwell Encyclopedia of Sociology, edited by G. Ritzer. Malden MA: Blackwell Publishing.

Ganzeboom, Harry B. G., Paul M. De Graaf, and Donald J. Treiman. 1992. “A Standard International Socio-Economic Index of Occupational Status." Social Science Research 21(1):1-56.

Gelman, Andrew and Eric Loken. 2014. "The Statistical Crisis in Science." American Scientist 102(6):460.

Gilbert, Dennis. 2014. The American Class Structure in an Age of Growing Inequality. Thousand Oaks, CA.

Gilens, Martin. 1995. "Racial Attitudes and Opposition to Welfare." The Journal of Politics 57(04):994-1014.

Gilens, Martin. 1996. "'Race Coding' and White Opposition to Welfare.” American Political Science Review 90(3):593-604.

Gilens, Martin. 2009. Why Americans Hate Welfare: Race, Media, and the Politics of Antipoverty Policy. Chicago, IL: The University of Chicago Press.

Gingrich, Jane and Silja Häusermann. 2015. "The Decline of the Working-Class Vote, the Reconfiguration of the Welfare Support Coalition and Consequences for the Welfare State." Journal of European Social Policy 25(1):50-75.

Gonthier, Frederic. 2017. "Parallel Publics? Support for Income Redistribution in Times of Economic Crisis.” European Journal of Political Research 56(1):92-114.

Granger, C. W. J. 1969. "Investigating Causal Relations by Econometric Models and CrossSpectral Methods." Econometrica 37(3):424-38.

Grisold, Andrea and Hendrik Theine. 2017. "How Come We Know? The Media Coverage of Economic Inequality.” International Journal of Communication 11:4265-84.

Grusky, David, ed. 2018. Social Stratification. Class, Race and Gender in Sociological Perspective. Fourth Edi. New York and Oxford: Routledge.

Gugushvili, Alexi, Erzsébet Bukodi, and John H. Goldthorpe. 2017. "The Direct Effect of Social Origins on Social Mobility Chances: 'Glass Floors' and 'Glass Ceilings' in Britain." European Sociological Review 33(2):305-16.

Hall, Peter A. and Kathleen Thelen. 2009. "Institutional Change in Varieties of Capitalism." 
Socio-Economic Review 7(1):7-34.

Hertel, Florian. 2017. Social Mobility in the 20th Century: Class Mobility and Occupational Change in the United States and Germany. Berlin: Springer.

Hill, Terrence D. and Andrew Jorgenson. 2018. "Bring out Your Dead!: A Study of Income Inequality and Life Expectancy in the United States, 2000-2010." Health \& Place 49:16.

Hirschman, A. O. and M. Rothschild. 1973. "The Changing Tolerance for Income Inequality in the Course of Economic Development." Quarterly Journal of Economics 87(4):54466.

House, Freedom. 2012. Democratic Governance Rankings 2012. www.freedomhouse.org.

Hox, Joop J. 2010. Multilevel Analysis: Techniques and Applications. 2nd Editio. New York: Routledge.

Hox, Joop J. and Ita G. G. Kreft. 1994. "Multilevel Analysis Methods.” Sociological Methods \& Research 22(3):283-99.

Huckfeldt, Robert, Eric Plutzer, and John Sprague. 1993. "Alternative Contexts of Political Behavior: Churches, Neighborhoods, and Individuals." The Journal of Politics 55(2):365-81.

Iversen, Torben and David Soskice. 2009. "Distribution and Redistribution: The Shadow of the Nineteenth Century." World Politics 61(03):438-86.

Jacoby, William G. 2000. "Issue Framing and Public Opinion on Government Spending." American Journal of Political Science 44(4):750-67.

Jacoby, William G. 2006. "Value Choices and American Public Opinion." American Journal of Political Science 50(3):706-23.

Jæger, Mads Meier. 2006. "Welfare Regimes and Attitudes Towards Redistribution: The Regime Hypothesis Revisited.” European Sociological Review 22(2):157-70.

Jæger, Mads Meier. 2013. "The Effect of Macroeconomic and Social Conditions on the Demand for Redistribution: A Pseudo Panel Approach.” Journal of European Social Policy 23(2):149-63.

Jerrim, John and Lindsey Macmillan. 2015. "Income Inequality, Intergenerational Mobility, and the Great Gatsby Curve: Is Education the Key?" Social Forces 94(2):505-33.

Kane, Emily W. 2017. "The Neoliberal Baseline? A Community-Based Exploration of Beliefs about Poverty and Social Policy." Journal of Poverty 1-23.

Kelley, Jonathan and M. D. R. Evans. 1993. "The Legitimation of Inequality: Occupational Earnings in Nine Nations.” American Journal of Sociology 99(1):75-125.

Kenworthy, Lane. 2007. "Toward Improved Use of Regression in Macro-Comparative Analysis." Comparative Social Research 24(3):343-50.

Kenworthy, Lane and Leslie McCall. 2008. "Inequality, Public Opinion, and Redistribution." Socio-Economic Review 6:35-68.

Kerr, William R. 2014. "Income Inequality and Social Preferences for Redistribution and Compensation Differentials." Journal of Monetary Economics 66:62-78.

Kevins, Anthony, Alexander Horn, Carsten Jensen, and Kees van Kersbergen. 2018. "Yardsticks of Inequality: Preferences for Redistribution in Advanced Democracies." Journal of European Social Policy 0958928717753579.

Klenner, Christina. 2013. "Wer Ernährt Wen? Auf Der Suche Nach Einem Neuen Leitbild." 
WSI Mitteilungen (3):210-12.

Korpi, Walter. 1985. "Economic Growth and the Welfare State: Leaky Bucket or Irrigation System?" European Sociological Review 1(2):97-118.

Korpi, Walter and Joakim Palme. 1998. "The Paradox of Redistribution and Strategies of Equality: Welfare State Institutions, Inequality, and Poverty in the Western Countries." American Sociological Review 63(5):661-87.

Krueger, Alan. 2012. The Rise and Consequences of Inequality.

Kulin, Joakim and Bart Meuleman. 2015. "Human Values and Welfare State Support in Europe: An East-West Divide?” European Sociological Review 31(4):418-32.

Kwon, Ronald and Michaela Curran. 2016. "Immigration and Support for Redistributive Social Policy: Does Multiculturalism Matter?" International Journal of Comparative Sociology 57(6):375-400.

Kwon, Roy. 2016. "Can We Have Our Cake and Eat It Too? Liberalization, Economic Growth, and Income Inequality in Advanced Industrial Societies." Social Forces 95(2):469-502.

Larsen, Christian Albrekt. 2008. "The Institutional Logic of Welfare Attitudes: How Welfare Regimes Influence Public Support.” Comparative Political Studies 41(2):145-68.

Linos, Katerina and Martin West. 2003. "Self-Interest, Social Beliefs, and Attitudes to Redistribution. Re-Addressing the Issue of Cross-National Variation." European Sociological Review 19(4):393-409.

Lübker, Malte. 2004. “Globalization and Perceptions of Social Inequality.” International Labour Review 143(1-23447):91-128.

Lupu, N. and J. Pontusson. 2011. "The Structure of Inequality and the Politics of Redistribution." American Political Science Review 105(2):316-36.

Mahler, Vincent A. and David K. Jesuit. 2006. "Fiscal Redistribution in the Developed Countries: New Insights from the Luxembourg Income Study1." Socio-Economic Review 4(3):483-511.

Mankiw, N. Gregory. 2013. "Defending the One Percent." Journal of Economic Perspectives 27(3):21-34.

Manza, Jeff and Clem Brooks. 2012. "How Sociology Lost Public Opinion: A Genealogy of a Missing Concept in the Study of the Political." Sociological Theory 30(2):89-113.

McCall, Leslie and Lane Kenworthy. 2009. “Americans' Social Policy Preferences in the Era of Rising Inequality." Perspectives on Politics 7(3):459-84.

Munafò, Marcus R., Brian A. Nosek, Dorothy V. M. Bishop, Katherine S. Button, Christopher D. Chambers, Nathalie Percie du Sert, Uri Simonsohn, Eric-Jan Wagenmakers, Jennifer J. Ware, and John P. A. Ioannidis. 2017. "A Manifesto for Reproducible Science." Nature Human Behaviour 1(1):21.

Neckerman, Kathryn M. and Florencia Torche. 2007. "Inequality: Causes and Consequences." Annual Review of Sociology 33(1):335-57.

OECD. 2017a. GDP at Parity Purchasing Power. accessed 22.06.2017.

OECD. 2017b. GDP Long-Term Forecast, 2009-2060. Long-term baseline projections.

OECD. 2018. Social Expenditures Database. accessed 01.04.2018: Organization for Economic Cooperation and Development.

Okun, Arthur M. 1975. Equality and Efficiency: The Big Tradeoff. Washington D.C.: The 


\section{Brookings Institution.}

van Oorschot, Wim. 2000. "Who Should Get What, and Why? On Deservingness Criteria and the Conditionality of Solidarity Among the Public." Policy \& Politics 28(1):33-48.

van Oorschot, Wim. 2006. "Making the Difference in Social Europe: Deservingness Perceptions Among Citizens of European Welfare States." Journal of European Social Policy 16(1):23-42.

Ortmanns, Verena and Silke L. Schneider. 2016. "Harmonization Still Failing? Inconsistency of Education Variables in Cross-National Public Opinion Surveys." International Journal of Public Opinion Research 28(4):562-82.

Papadakis, Elim and Clive S. Bean. 1993. "Popular Support for the Welfare State: A Comparison between Institutional Regimes.” Journal of Public Policy 13(3):227-54.

Patashnik, Eric M. and Julian E. Zelizer. 2013. “The Struggle to Remake Politics: Liberal Reform and the Limits of Policy Feedback in the Contemporary American State." Perspectives on Politics 11(04):1071-87.

Petersen, Michael Bang, Rune Slothuus, Rune Stubager, and Lise Togeby. 2011. "Deservingness Versus Values in Public Opinion on Welfare: The Automaticity of the Deservingness Heuristic.” European Journal of Political Research 50(1):24-52.

Pfau-Effinger, Birgit. 2005. "Culture and Welfare State Policies: Reflections on a Complex Interrelation." Journal of Social Policy 34(1):3-20.

Pickett, Kate and Richard Wilkinson. 2015. "Income Inequality and Health: A Causal Review." Social Science \& Medicine 128:316-26.

Pierson, Paul. 1993. "When Effect Becomes Cause: Policy Feedback and Political Change." World Politics 45(4):595-628.

Pierson, Paul. 1996. “The New Politics of the Welfare State.” World Politics 48(2):143-79.

Pierson, Paul. 1998. "Irresistible Forces, Immovable Objects: Post-Industrial Welfare States Confront Permanent Austerity." Journal of European Public Policy 5(4):539-60.

Pierson, Paul. 2000a. "Increasing Returns, Path Dependence, and the Study of Politics." The American Political Science Review 94(2):251-67.

Pierson, Paul. 2000b. "Not Just What, but When: Timing and Sequence in Political Processes." Studies in American Political Development 14(01):72-92.

Piketty, Thomas. 2014. Capital in the Twenty-First Century. Translatio. Cambridge, MA: Harvard University Press.

Piketty, Thomas and Emmanuel Saez. 2014. "Inequality in the Long Run.” Science 344(6186):838-43.

Ragin, Charles. 1987. The Comparative Method. Moving Beyond Qualitative and Quantitative Strategies. Berkeley: The University of California Press.

Rambotti, Simone. 2015. "Recalibrating the Spirit Level: An Analysis of the Interaction of Income Inequality and Poverty and Its Effect on Health." Social Science \& Medicine 139:123-31.

Raudenbush, Stephen W. and Anthony S. Bryk. 2002. Hierarchical Linear Models: Applications and Data Analysis Methods. Vol. 1. 2nd Editio. Thousand Oaks, CA: Sage Publications.

Rehm, Philipp, Jacob S. Hacker, and Mark Schlesinger. 2012. "Insecure Alliances: Risk, Inequality, and Support for the Welfare State." American Political Science Review 
106(2):386-406.

Roller, Edeltraud. 1994. "Ideological Basis of the Market Economy: Attitudes toward Distribution Principles and the Role of Government in Western and Eastern Germany." European Sociological Review 10(2):105-17.

Schmidt-Catran, Alexander W. 2016. "Economic Inequality and Public Demand for Redistribution: Combining Cross-Sectional and Longitudinal Evidence." SocioEconomic Review 14(1):119-40.

Schmidt-Catran, Alexander W. and Malcolm Fairbrother. 2016. "The Random Effects in Multilevel Models: Getting Them Wrong and Getting Them Right." European Sociological Review 32(1):23-38.

Schmidt-Catran, Alexander W. and Dennis C. Spies. 2016. "Immigration and Welfare Support in Germany." American Sociological Review .

Solt, Frederick. 2016. “The Standardized World Income Inequality Database.” Social Science Quarterly 97(5):1267-81.

Solt, Frederick. 2017. "The Standardized World Income Inequality Database."

Soroka, Stuart N. and Christopher Wlezien. 2010. Degrees of Democracy: Politics, Public Opinion and Policy. Cambridge: Cambridge University Press.

Soss, Joe and Sanford F. Schram. 2007. "A Public Transformed? Welfare Reform as Policy Feedback.” The American Political Science Review 101(1):111-27.

Steele, Liza G. 2015. "Income Inequality, Equal Opportunity, and Attitudes About Redistribution.” Social Science Quarterly 96(2):444-64.

Steensland, Brian. 2006. "Cultural Categories and the American Welfare State: The Case of Guaranteed Income Policy.” American Journal of Sociology 111(5):1273-1326.

Stiglitz, Joseph E. 2000. "Capital Market Liberalization, Economic Growth, and Instability." World Development 28(6):1075-86.

Stock, James H. and Mark W. Watson. 2001. "Vector Autoregressions.” Journal of Economic Perspectives 15(4):101-15.

Stockemer, Daniel, Bernadette LaMontagne, and Lyle Scruggs. 2012. "Bribes and Ballots: The Impact of Corruption on Voter Turnout in Democracies." International Political Science Review 34(1):74-90.

Sundberg, Trude and Peter Taylor-Gooby. 2013. "A Systematic Review of Comparative Studies of Attitudes to Social Policy." Social Policy \& Administration 47(4):416-33.

Svallfors, Stefan. 1997. "Worlds of Welfare and Attitudes to Redistribution: A Comparison of Eight Western Nations." European Sociological Review 13(3):283-304.

Thelen, Kathleen. 2014. Varieties of Liberalization and the New Politics of Social Solidarity. Cambridge: Cambridge University Press.

VanHeuvelen, Tom. 2017. "Unequal Views of Inequality: Cross-National Support for Redistribution 1985-2011." Social Science Research 64:43-66.

VanHeuvelen, Tom and Kathy Copas. 2018. "The Intercohort Dynamics of Support for Redistribution in 54 Countries, 1985-2017." Societies 8(69):1-22.

Wade, Robert. 2012. "Why Has Income Inequality Remained on the Sidelines of Public Policy for So Long?" Challenge 55(3):21-50.

Weakliem, David L., Robert Andersen, and Anthony F. Heath. 2005. "By Popular Demand: The Effect of Public Opinion on Income Inequality." Comparative Sociology 4:261-84. 
Weale, Albert. 1990. "Equality, Social Solidarity, and the Welfare State." Ethics 100(3):473488 CR-Copyright \&\#169; 1990 The University.

Western, M. M. B. 1999. "Inequality in Earnings at the Close of the Twentieth Century." Annual Review of Sociology 253998:623-57.

Wicherts, Jelte M., Coosje L. S. Veldkamp, Hilde E. M. Augusteijn, Marjan Bakker, Robbie C. M. van Aert, and Marcel A. L. M. van Assen. 2016. "Degrees of Freedom in Planning, Running, Analyzing, and Reporting Psychological Studies: A Checklist to Avoid p-Hacking." Frontiers in Psychology 7:1832.

WID. 2018. World Inequality Database. Paris: The World Inequality Lab.

Wilensky, Harold L. 1975. The Welfare State and Equality: Structural and Ideological Roots of Public Expenditure. Berkeley: University of California Press.

Wilkinson, Richard and Kate Pickett. 2009. "Income Inequality and Social Dysfunction." Annual Review of Sociology 35:493-511.

Wimmer, Andreas and Yuval Feinstein. 2010. "The Rise of the Nation-State across the World, 1816 to 2001.” American Sociological Review 75(5):764-90.

Wright, Graham. 2017. "The Political Implications of American Concerns About Economic Inequality." Political Behavior 1-23.

Wuttke, Alexander. 2018. "Why Too Many Political Science Findings Cannot Be Trusted and What We Can Do About It: A Review of Meta-Scientific Research and a Call for Academic Reform." Politische Vierteljahresschrift.

Young, Cristobal. 2018. "Model Uncertainty and the Crisis in Science." Socius $4: 2378023117737206$. 


\section{ApPendix TABles ${ }^{16}$}

$$
\begin{aligned}
\text { Variable } & \text { Coefficient } \\
\text { Age } & -0.004^{\star \star} \\
\text { Age } 2 & 0.000^{\star \star} \\
\text { Female } & 0.124^{\star \star \star} \\
\text { Full } & -0.082^{\star \star \star} \\
\text { Education } & -0.016^{\star \star \star} \\
\text { ISEI } & -0.011^{\star \star \star} \\
\text { constant } & 4.274^{\star \star \star}
\end{aligned}
$$

Variance-Components

\begin{tabular}{lcc}
\multicolumn{1}{c}{ Type } & Intercept & Variance \\
\hline Level-2 (country-time) & $-1.079^{\star \star \star}$ & 0.116 \\
Level-3 (country) & $-1.859^{\star \star \star}$ & 0.024 \\
Level-1 (residual) & $0.104^{\star \star \star}$ & 1.232 \\
\hline
\end{tabular}

${ }^{*} p<.01{ }^{* m p} p<001$

Observafons: level- $0=96,752$; level- $2=91$; level- $3=19$

Table 3. Support for Redistribution MLM for

Composition Adjustments at Level-1 (jk)

\footnotetext{
${ }^{16}$ For all additional information see the anonymized Online Appendix: https://osf.io/gzsmb/
} 


\begin{tabular}{|c|c|c|c|c|c|c|c|c|c|}
\hline \multicolumn{10}{|c|}{ Variable labels - Support_Redistribution ${ }_{j k}(\mathbf{G}), \operatorname{Top}_{10}(\mathbf{C}), \operatorname{Gini}_{j k}(\mathbf{N})$, Frasier $_{j k}(\mathbf{F}), G_{j k}(\mathbf{P}), S_{0 C X}(\mathbf{S})$} \\
\hline set & $\begin{array}{l}\text { consistency }\end{array}$ & $\begin{array}{l}F Q 6 \text { (G N } \\
\text { coverage }\end{array}$ & $\begin{array}{l}\text { S) } \cdots \\
\text { common }\end{array}$ & bestfit\# & set & $\begin{array}{l}\text { - - - Mode } \\
\text { consistency }\end{array}$ & $\begin{array}{l}\text { QQ4 (G N F } \\
\text { coverage }\end{array}$ & $\begin{array}{l}\text { P S) - - - - } \\
\text { common }\end{array}$ & best fit\# \\
\hline nps & 0.886 & 0.906 & no & 9 & cnfps & 0.897 & 0.943 & no & 5 \\
\hline $\mathrm{npS}$ & 0.874 & 0.938 & yes & 5 & cnfpS & 0.884 & 0.976 & yes & 3 \\
\hline $\mathrm{nPs}$ & 0.868 & 0.951 & yes & 1 & cnfPs & 0.924 & 0.969 & yes & 0 \\
\hline nPS & 0.911 & 0.952 & no & 0 & cnfPS & 0.923 & 0.973 & yes & 0 \\
\hline NpS & 0.869 & 0.906 & no & 6 & cnFps & 0.903 & 0.928 & no & 4 \\
\hline NPs & 0.865 & 0.864 & no & 12 & cnFpS & 0.896 & 0.943 & no & 2 \\
\hline \multicolumn{5}{|c|}{ consistency $<0.850$ are NPS (22), NPS (30) } & cnFPs & 0.888 & 0.949 & yes & 1 \\
\hline \multirow{4}{*}{\multicolumn{5}{|c|}{. . . . Model FQ5 (G N F P S) . . . . . . }} & cnFPS & 0.915 & 0.956 & no & 0 \\
\hline & & & & & cNfps & 0.889 & 0.972 & yes & 5 \\
\hline & & & & & cNfpS & 0.898 & 0.957 & yes & 3 \\
\hline & & & & & CNPS & 0.928 & 0.962 & no & 0 \\
\hline set & consistency & coverage & common & bestfit\# & cNIPS & 0.926 & 0.958 & no & 0 \\
\hline nfps & 0.898 & 0.943 & no & 5 & cNFps & 0.875 & 0.916 & no & 7 \\
\hline nfpS & 0.886 & 0.976 & yes & 3 & cNFpS & 0.887 & 0.94 & no & 3 \\
\hline $\mathrm{nfPs}$ & 0.925 & 0.969 & no & 0 & cNFPs & 0.878 & 0.922 & no & 8 \\
\hline nfPS & 0.921 & 0.973 & yes & 0 & cNFPS & 0.894 & 0.908 & no & 11 \\
\hline nFps & 0.904 & 0.929 & no & 4 & Cnfps & 0.909 & 0.976 & yes & 0 \\
\hline nFpS & 0.898 & 0.938 & no & 2 & CnfpS & 0.907 & 0.982 & yes & 0 \\
\hline nFPs & 0.89 & 0.95 & yes & 1 & CnIPs & 0.916 & 0.973 & yes & 0 \\
\hline nFPS & 0.914 & 0.951 & no & 0 & CnfPS & 0.915 & 0.976 & yes & 0 \\
\hline Nfps & 0.892 & 0.971 & yes & 5 & CnFps & 0.89 & 0.968 & yes & 0 \\
\hline NfpS & 0.901 & 0.946 & no & 3 & $\mathrm{CnFpS}$ & 0.904 & 0.964 & yes & 0 \\
\hline NPPs & 0.931 & 0.947 & no & 1 & CnFPs & 0.887 & 0.966 & yes & 0 \\
\hline NIPS & 0.899 & 0.926 & no & 5 & CnFPS & 0.908 & 0.96 & no & 0 \\
\hline NFps & 0.876 & 0.912 & no & 7 & CNfps & 0.903 & 0.976 & yes & 0 \\
\hline NFpS & 0.892 & 0.93 & no & 3 & CNfpS & 0.911 & 0.968 & yes & 0 \\
\hline NFPs & 0.867 & 0.865 & no & 21 & CNPS & 0.923 & 0.948 & no & 1 \\
\hline NFPS & 0.889 & 0.824 & yes & 25 & CNAPS & 0.893 & 0.925 & no & 5 \\
\hline \multicolumn{5}{|c|}{ consistency $<0.850$ are none } & CNFps & 0.879 & 0.945 & no & 0 \\
\hline & & & & & CNFpS & 0.898 & 0.944 & no & 0 \\
\hline & & & & & CNFPS & 0.879 & 0.878 & no & 13 \\
\hline & & & & & CNFPS & 0.903 & 0.843 & yes & 14 \\
\hline \multicolumn{10}{|c|}{ consistency $<0.850$ are none } \\
\hline
\end{tabular}

Table 8. Fuzzy Set Qualitative Comparative Analysis of the Outcome Support for Redistribution, within-country variance only 


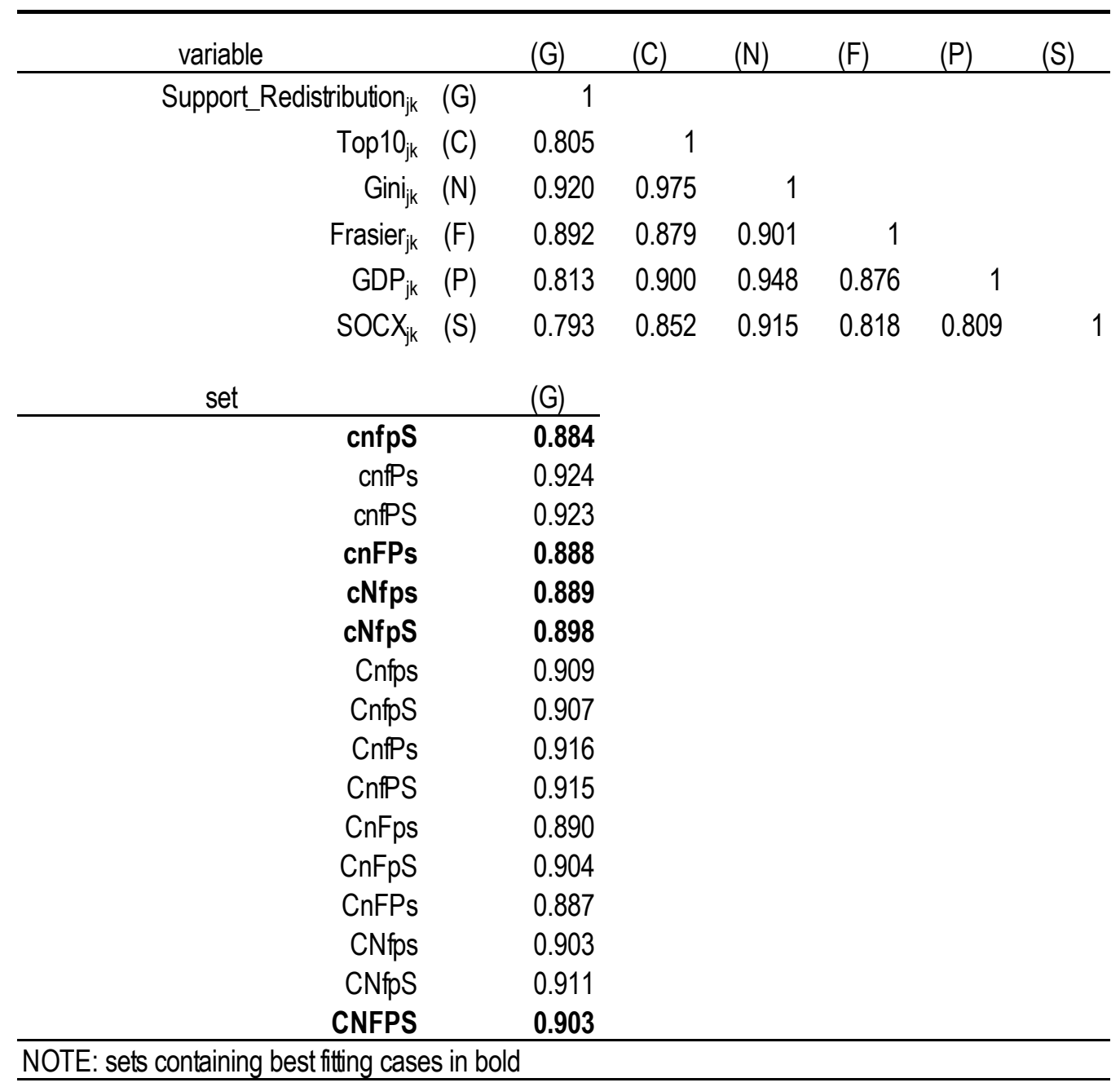

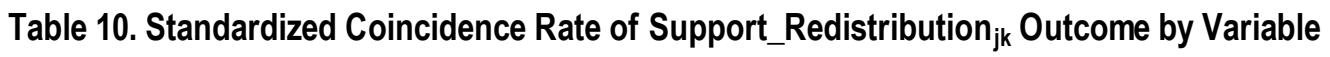
and by SET in fsQCA, taken from Model FQ3 from Table 8 in the Appendix 